\title{
Integrative Role of Albumin: Evolutionary, Biochemical and Pathophysiological Aspects
}

\author{
D. A. Belinskaia ${ }^{a, *}$, P. A. Voronina ${ }^{a}$, and N. V. Goncharov ${ }^{a, b}$ \\ ${ }^{a}$ Sechenov Institute of Evolutionary Physiology and Biochemistry of the Russian Academy of \\ Sciences, St. Petersburg, Russia \\ ${ }^{b}$ Research Institute of Hygiene, Occupational Pathology and Human Ecology, p/o Kuzmolovsky, \\ Vsevolozhsky District, Leningrad Region, Russia \\ *e-mail: daria.belinskaya@iephb.ru \\ Received February 26, 2021 \\ Revised April 2, 2021
}

Accepted April 2, 2021

\begin{abstract}
Being one of the main proteins in the human body and many animal species, albumin plays a crucial role in the transport of various ions, electrically neutral molecules and in maintaining the colloidal osmotic pressure of the blood. Albumin is able to bind almost all known drugs, many nutraceuticals and toxic substances, determining their pharmaco- and toxicokinetics. However, albumin is not only the passive but also the active participant of the pharmacokinetic and toxicokinetic processes possessing a number of enzymatic activities. Due to the thiol group of Cys34, albumin can serve as a trap for reactive oxygen and nitrogen species, thus participating in redox processes. The interaction of the protein with blood cells, blood vessels, and also with tissue cells outside the vascular bed is of great importance. The interaction of albumin with endothelial glycocalyx and vascular endothelial cells largely determines its integrative role. This review provides information of a historical nature, information on evolutionary changes, inflammatory and antioxidant properties of albumin, on its structural and functional modifications and their significance in the pathogenesis of some diseases.
\end{abstract}

DOI: $10.1134 / \mathrm{S} 002209302106020 \mathrm{X}$

Keywords: albumin, blood plasma, oxidative stress, endothelium, glycocalyx, transporting function, transcytosis

\section{INTRODUCTION: EVOLUTIONARY, GENETIC, STRUCTURAL AND ENZYMATIC FEATURES OF ALBUMIN}

Albumin probably was the first protein that physicians of ancient civilizations paid attention to. Thus, Hippocrates in the $\mathrm{V}$ century $\mathrm{BC}$ associated kidney disease in his patients with the presence of foamy urine, which, as now is evident, becomes so due to the presence of albumin in it. The first recorded attempts to extract albumin from urine using vinegar were made in the 16th century by Paracelsus, but it was only in 1894 that Gurber first crystallized albumin from horse serum [1]. Since at first the object of the study and the source of albumin was blood serum, the definition of "serum albumin" was fixed for albumin, although modern technologies for the isolation of 
albumin deal with blood plasma [2]. At the same time, the initial reason for the frequent use of the phrase "serum albumin" is the need to emphasize its difference from egg, milky and plant albumins.

Serum albumin belongs to the albuminoid superfamily, which also includes vitamin D-binding protein (VDP), alpha-fetoprotein and alphaalbumin (afamin); accordingly, the gene family includes the genes of these four globular proteins [3]. This family is found only in vertebrates [4], so serum albumin is available not only in mammals, but also in birds, some species of frogs, lampreys and salamanders (an exhaustive list is presented on the website albumin.org). Quantitatively, albu$\mathrm{min}$ is the dominant plasma or serum protein and, along with other representatives of the family, acts as a carrier of endogenous and exogenous substances, including thyroxine, fatty acids and drugs, while the main "cargo" of VDP is 25-hydroxyvitamin D [3]. All albuminoids are evolutionarily related to serum albumin $[5,6]$. This is one of the most evolutionarily variable proteins, thus, in different species, the differences between albumin domains are $70-80 \%$. Clearly, this is due to the development in the course of evolution of its special binding characteristics in relation to new ligands-hormones, metabolites, toxins. In contrast to albumin, the differences in the structure of retinol-binding protein are on the average $40 \%$, and in the structure of histones-less than $10 \%$ [7]. The study of albuminoid genes showed that the sites of binding of fatty acids and thyroxine, the contact surface with the neonatal Fc receptor, as well as the amino acid residues of albumin forming a pocket for binding prostaglandins were most affected by selection [3]. However, despite on the fact that albumin is a rapidly evolving protein, it has two conservative characteristics, one of them is a tertiary structure, which consists mainly of helical sections in the complete absence of any $\beta$-sheet fragments, and other one is a pattern of disulfide bonds, there are seventeen ones in the albumin molecule [8]. Due to the presence of serum albumin in all vertebrates, it can be a kind of indicator of the time of evolution of the species [9]. Thus, as a result of the study of the phylogenetic tree of primate albumins, it was found that orangutans were the first to separate from primates, gorillas followed, later chimpanzees and, finally, humans [10].

The ancestral albumin gene underwent a tripling in the process of evolution about 525 million years ago [11], when vertebrates first appeared. The molecule of human serum albumin (HSA) consists of 585 amino acid residues forming one polypeptide chain with a molecular weight of $66439 \mathrm{Da}$, however, these figures may vary due to species differences, genetic and posttranslational modifications. The architecture of albumin is predominantly spiral and consists of three domains with very similar shapes, which together form the shape of a heart. However, in the lamprey, also they are called "living fossil", albumin consists of seven domains [12]. Four canonical representatives of the human albuminoid family are located in tandem in the 4q13.3 region [13]. Gene alb of HSA consists of 16961 nucleotide pairs from the putative "cap site" to the first poly(A) attachment site. It is divided into 15 exons, which are symmetrically placed in three domains. The precursor of serum albumin (preproalbumin) has an N-terminal peptide that cleaves off before the protein leaves the rough endoplasmic reticulum. The product (proalbumin) is transported to the Golgi apparatus. Limited proteolysis occurs in secretory granules and mature non-glycosylated albumin is secreted into the extracellular medium [1]. Protein synthesis occurs mainly in hepatocyte polysomes; a healthy adult produces $10-15 \mathrm{~g}$ of albumin per day, which is almost $10 \%$ of all protein synthesis in the liver [14]. About $1 / 3$ of the synthesized albumin remains in the plasma, while most of it passes into the intercellular space of muscle tissue and skin. The synthesis of albumin in the liver largely depends on colloidal osmotic pressure, gene expression is regulated by the feedback principle [15].

Albumin is produced only by hepatocytes. To deliver the newly synthesized albumin to the basolateral side of the cells and the subsequent secretion of albumin into the bloodstream, the neonatal $\mathrm{Fc}$ receptor $(\mathrm{FcRn})$ is needed. $\mathrm{FcRn}$ is localized mainly inside cells and, in addition to $\mathrm{IgG}$, can bind albumin. The absence of FcRn expression in hepatocytes leads to an increase in the level of albumin in bile, its intracellular accumulation and a decrease in the level of circulating albumin [16]. For example, during oncogenesis, 
cells may lose or suppress the expression of FcRn. In these cases, the cells will not be able to process albumin after its internalization, instead it decomposes, providing the tumor with nutrients and promoting its growth. Due to the peculiarities of the structure and the absence of a direct connection with immune responses, FcRn was classified as a non-classical FcyR [17]. IgG and albumin are the major serum proteins that have a relatively long half-life in serum largely due to their interaction with FcRn, which saves them from intracellular degradation through the mechanism of cellular recycling.

All members of the albumin family are watersoluble and moderately soluble in concentrated salt solutions. The key physico-chemical properties of serum albumin are that this protein is acidic, highly soluble and very stable and can withstand a temperature of $60^{\circ} \mathrm{C}$ for $10 \mathrm{~h}$ [1]. HSA has in total 83 positively charged amino acid residues (Arg + Lys) and 98 negatively charged residues (Asp + Glu) with a theoretical pI value of 5.12. The difference between albumin and other blood proteins is that normally it is non-glycosylated (non-glycated, if we mean exclusively non-enzymatic glycosylation), although even a small percentage of glycated albumin makes a significant contribution to the pathogenesis of diabetes and other diseases. Glycation by lysine residues has been most well studied. There are also known redox modifications of albumin such as cysteinylation, homocysteinylation and sulfinylation of Cys34 [18]. The albumin molecule has 17 disulfide bonds and one free thiol group in Cys34, which determines the participation of albumin in redox reactions. According to the redox state of Cys34, there are three isoforms of HSA: mercaptalbumin (reduced albumin, HMA) and non-mercaptalbumin-1 and -2 (variants of oxidized albumin HNA-1 and HNA-2) [19].

There are dozens of genetic variants of HSA (the full list is available on the website albumin.org). The possible effects of some point mutations on the ligand-binding ability of HSA were studied by the interaction of five structurally characterized genetic variants of the protein with highaffinity for albumin drugs such as warfarin, salicylate and diazepam [20]. Equilibrium dialysis data show a noticeable decrease in the high-affinity binding of all three ligands to HSA Canterbury (313lys $\rightarrow$ Asn) and HSA Parklands (365asp $\rightarrow$ His). In the case of HSA Verona (570glu $\rightarrow$ Lys), change of affinity wasn't detected. Affinity to the modification of HSA Niigata (269asp $\rightarrow$ Gly) was reduced only for salicylate; and affinity to the modification of HSA Roma (321glu $\rightarrow$ Lys) was reduced for salicylate and diazepam. In half of the cases, the decrease in the primary association constant reached one order of magnitude, which led to an increase in the unrelated fraction of pharmaceuticals by at least $500 \%$ with therapeutically relevant molar ratios of the pharmaceutical and protein. The main reason for the decrease in ligand binding is conformational changes in the 313-365 region, while changes in the charge of the molecule play a secondary role [20].

Albumin can bind various endogenous and exogenous ligands such as water and metal cations, fatty acids, hormones, bilirubin, metalloporphyrins, nitric oxide, aspirin, warfarin, ibuprofen, phenylbutazone, etc. [21]. The binding of low molecular weight ligands occurs at two main sites Sudlow site I in subdomain IIA and Sudlow site II in subdomain IIIA and also in several secondary sites. When albumin interacts with various substances, cooperative and allosteric modulation effects occur, which are usually inherent in multimeric macromolecules [22, 23]. Albumin is not only passive, but also an active participant in pharmacokinetic and toxicokinetic processes. Numerous experiments have shown that albumin possesses the (pseudo)esterase, phosphatase, peroxidase and other types of enzymatic activities. The enzymatic activity of the protein is considered in more details in our previous reviews [2426]. Previously, it was suggested that some simple reactions catalyzed by serum albumin with Michaelis-Menten kinetics include nonspecific substrate binding and catalysis by local functional groups [27]. Most enzymes are able to catalyze physiologically irrelevant (secondary, "promiscuous") reactions in addition to those reactions that have become the main ones for them as a result of evolution; the number of "promiscuous" reactions turned out to be quite large when considering the issue in detail $[28,29]$, so it is more the rule than the exception. However, the catalytic "illegibility" of albumin, in our opinion, arose as a 
result of the loss (and not the acquisition) of some specialized activities, for example, such as the activity of esterases (hydrolases) with digestive functions. The so-called Kemp elimination, a prototypical reaction of proton cleavage from carbon, plays a certain role in the mechanism of albumin "promiscuity". The reaction occurs in the Stern layer, at the interface between the micelle head or the protein surface and water, so that a significant acceleration of the reaction can be achieved independently of the spatial substrate location [30, 31]. The mechanism of Kemp elimination in protein molecules is associated with the presence of aromatic amino acid residues (Trp, Tyr, Phe) that provide stacking interaction with hydrogen bond donors (Lys, Arg, Ser, Tyr, His, water molecule) [32]. Previously, we proposed an explanation for the albumin-mediated hydrolysis of some substrates by the existence of catalytic dyads (as opposed to catalytic triads in cholinesterases) His-Tyr or Lys-Tyr, in which histidine or lysine residues function as acid residues and proton donors, and the tyrosine residue is a catalytic base [24].

\section{REDOX MODULATION AND REDOX ACTIVITY OF ALBUMIN}

The redox status of the thiol group of Cys34 residue ensures the heterogeneity of albumin isoforms: human mercaptalbumin (HMA) has a free thiol form; a mixed disulfide with Cys or cysteinylglycine (CysGly), to a lesser extent with homocysteine (HCys) or glutathione $(\mathrm{GSH})$, is called nonmercaptalbumin-1 (HNA-1); albumin with a cysteine residue oxidized to sulfinic or sulfonic acid is called HNA-2. In healthy young people, the content of HMA is $70-80 \%$, HNA-1 is $20-30 \%$, while HNA-2 is $2-5 \%$ of the total amount of albumin [33]. Oxidized forms of albumin differ in physical and chemical properties from the reduced form. Thus, an increase in the colloidal osmotic pressure of oxidized albumin was shown in in vitro experiments using hypochlorite and was also found in patients with chronic kidney disease [34]. The affinity for the endogenous ligands bilirubin and tryptophan, as well as for the exogenous pharmaceuticals warfarin and diazepam, decreases in proportion to the level of oxidized albumin (cysteinylation of Cys34) [35]. Affinity for lipids also differs: proatherosclerotic lysophosphatidylcholine and lysophosphatidic acid have a higher affinity for the oxidized isoform, while anti-atherosclerotic derivatives of eicosapentaenoic and docosahexaenoic acids have a higher affinity for the reduced isoform of albumin [36].

The residues HSA subject to oxidation are primarily Cys34, but also tyrosine residues Tyr84, 138, 140, 161, 263, 319, 332, 334, 353 and 370, methionine residues Met87 and Met123, tryptophan residue Trp214 [37]. In the blood plasma of a healthy person, about $80 \%$ of all thiols are in the Cys34 residue of albumin [38]. It is able to stoichiometrically inactivate hydrogen peroxide, peroxynitrite, superoxide anion and hypochlorous acid, while being oxidized to sulfenic acid (HSA$\mathrm{SOH})[39,40]$. Under oxidative stress caused by reactive oxygen species (ROS), Cys34 forms a disulfide with free cysteine or glutathione; oxidation changes the three-dimensional structure of HSA and affects the binding of many xenobiotics (pharmaceuticals and toxic substances). Depending on the nature and state of oxidation of HSA, oxidized derivatives can be divided into reversible (HNA-1) and irreversible (HNA-2). It is assumed that both HNA-1 and HNA-2 cause the development of inflammatory processes, which is associated with an increase in the level of proinflammatory cytokines and markers of damage to certain tissues and organs [37]. Recent studies suggest that oxidized albumin isoforms are independent pathogenetic factors of many common and socially significant diseases, and their level is closely related to human dietary habits [19]. However, it remains largely unclear what is the specificity of the response of different tissues to the action of different forms of modified albumin.

The list of albumin activities associated with redox modulation of blood plasma and intercellular fluid includes the activity of thioesterase [41, 42], glutathione peroxidase and cysteine peroxidase, as well as the activity of peroxidase in relation to lipid hydroperoxides [43-45]. The important role of Cys392 and Cys438 of albumin should be noted. These residues form a redoxsensitive disulfide in the complex of albumin with palmitoyl-CoA [45]. Cys34 is the most important 
trap of ROS, although not the only one: six methionine residues also contribute to the antioxidant properties of albumin [39, 46]. Residues Met87 and Met123 are commonly oxidized to methionine sulfoxide, especially in renal failure and diabetes.

Albumin is involved in the transport of copper [47], which is a cofactor of many enzymes and a participant in redox reactions and signaling pathways in the body in health and disease [48]. The main binding site for $\mathrm{Cu}(\mathrm{II})$ cations is the N-terminal region of human albumin Asp-Ala-His-Lys (N-terminal site, NTS) [49]. It is assumed that the albumin structure contains a site for the binding of $\mathrm{Cu}(\mathrm{I})$. Using spectroscopic and computational methods, it was shown that the imidazole rings of two histidines play a key role in the binding of the $\mathrm{Cu}(\mathrm{I})$ cation [50]. The N-terminal region of HSA in a complex with copper ions has superoxide dismutase activity [51]. In addition, the prooxidant properties of albumin should be noted: albumin-bound $\mathrm{Cu}^{2+}$ ions enhance the formation of an ascorbate radical, followed by oxidation of the formed $\mathrm{Cu}^{+}$ions with molecular oxygen and protons again to $\mathrm{Cu}^{2+}[52]$.

The redox activity of albumin can be supplemented by the cyanide detoxification reaction with the formation of thiocyanate, which is catalyzed by regions of the IIIA subdomain without the participation of Tyr411 [53]. The percentage of oxidized albumin serves as one of the biomarkers of oxidative stress accompanying various diseases: for example, the level of Cys34-cysteinylated albumin is significantly increased in patients with diabetes mellitus, liver and kidney diseases [35]. In kidney disease, excessive ROS production contributes to oxidative damage, inflammation, endothelial dysfunction, and renal fibrosis [54]. Chronic kidney disease is common in diabetic patients, so glycated albumin is believed to be the main cause of kidney damage, although glycated and oxidized albumin has not been compared. The negative effects of albumin (both modified and unmodified) on tubular epithelial cells are not well understood. Albumin oxidation is thought to precede or occur in the early stages of chronic kidney disease. Albumin in healthy people partially overcomes the glomerular filtration barrier, but is reabsorbed by receptor-mediated endocyto- sis in proximal $(71 \%)$ and distal tubular cells (26\%) [37]. Albumin binds to the megalin-cubulin complex receptor and is directed to the clathrin-coated vesicles, followed by endocytosis and endosome acidification, which causes albumin dissociation from the megalin-cubulin complex and albumin binding to FcRn. Albumin is then either transferred to the lysosomes or returned to the blood via the transcytosis route, while the receptors are subject to recycling. However, the level of oxidized plasma albumin correlates with a decrease in the glomerular filtration rate. Oxidized albumin has a direct effect on neutrophils, increasing the levels of lipocalin associated with neutrophil gelatinase, which is a biomarker of renal damage. Moreover, oxidized albumin in patients with kidney disease independently correlates with higher plasma levels of the proinflammatory cytokines TGF- $\beta 1, \mathrm{TNF}-\alpha, \mathrm{IL}-1 \beta$, and IL-6 [37].

Fatty acids appear to play an important role in regulating the antioxidant properties of albumin [52]. The binding of fatty acids by albumin changes the conformation of Sudlow sites I and II and increases the fluorescence quantum yield of dansylamide (Sudlow site I ligand) and dansylsarcosine (Sudlow site II ligand); in addition, the fatty acids increased the steric availability of the Cys34 thiol group and enhanced its reactivity with 5,5'-dithiobis-2-nitrobenzoic acid (DTNB). Thus, the binding of fatty acids creates the prerequisites for the simultaneous regulation of two important functions of the protein, transport and antioxidant [52]. In addition, albumin enhances the antioxidant status of the organism due to the binding of bilirubin (ligand of the Site III [55]) and polyunsaturated fatty acids that interact with the residues Arg117, Lys351, and Lys475 [39].

\section{GLYCATED ALBUMIN IS A BIOMARKER AND PATHOGENETIC FACTOR OF DIABETES MELLITUS. GLYCATION END PRODUCTS AND THEIR RECEPTORS}

Diabetes mellitus (DM) is like a global epidemic, which is growing at an alarming rate and is associated with an increase in the mortality rate of the population. In 2018, the number of diabetic patients in the USA was 34.2 million. Worldwide, 
their number is 425 million people, and it is expected that by 2045 this figure will grow to 629 million [56]. Gestational diabetes affects from 2 to $14 \%$ of pregnant women in the USA annually [57]. There is an increase in the process of nonenzymatic condensation of sugars with nucleic acids, proteins and lipids in diabetic patients, and that ultimately forms advanced glycation end products (AGE), which lead to disruption of cell function and cytotoxic effects, so they are called glycotoxins. AGE can be formed as a result of physiological processes when they are not balanced by detoxification mechanisms, or enter the body from external sources such as food, cigarette smoke and air pollution. Their accumulation leads to inflammation and oxidative stress, mainly through activation of specific AGE receptors (RAGE, AGER) [58]. RAGE was first described in 1992, later RAGE isoforms were identified: AGER-1, 2, 3, as well as CD36 scavenger receptor $[59,60]$. AGER-2 are involved in the initiation of inflammatory processes, whereas AGER-1, -3 and CD36 receptors are responsible for detoxification of AGE [58, 61, 62]. RAGE is a receptor pertaining to the immunoglobulin superfamily; its ligand-binding domain recognizes, in addition to AGE, a large number of molecules, among which the most important are S100 proteins, high mobility group box-1 protein (HMGB1), $\beta$-amyloid and antigenic macrophage complex 1 (Mac-1) [63]. That is, RAGE acts as a non-specific pattern recognition receptor that can function as an extracellular sensor [58]. Glycated foods and RAGE activation are associated with the pathophysiology of many metabolic diseases, such as type 2 DM, food allergies, asthma, chronic obstructive pulmonary disease, acute renal failure, Alzheimer's disease, polycystic ovary syndrome [64-66]. AGE promotes carcinogenesis in chronic local inflammation induced by Helicobacter pylori [67].

Signaling pathways during the activation of RAGE include p21ras, MAP kinases, Rho GTPases, N-terminal kinase Jun (JNK) and JAK/STAT, which lead to the migration of transcription factors into the nucleus and the expression of genes which regulate chemotaxis, cell activation and proliferation [58]. NF- $\kappa \mathrm{B}$, NFAT, STAT, AP-1, ERK1/2 and the protein binding the cAMP-sensitive element bind to their specific promoters for transcription of genes encoding pro-inflammatory cytokines (for example, IL-1, IL-2 and IL-4), pro-apoptotic proteins (for example, p53-Bax, which initiates the cascade of caspases) and surface proteins, such as endothelial cell adhesion molecules [68-70]. RAGE is constitutively expressed in many tissues, whereas RAGE hyperactivation causes stimulation of the PI3K-PKB-IKK pathway, which leads to binding of $N F-\kappa B$ on the RAGE promoter and autoamplification of expression [58]. Another selfamplification loop is that AGE induces oxidative stress through RAGE activation followed by hyperactivation of NADPH oxidases, ROS generation, increased $\mathrm{AGE}$ and increased RAGE expression [71]. RAGE expression may increase not only due to the effects of AGE, but also due to the effects of proinflammatory cytokines [72]. AGE-activated endothelial cells "attract" lymphocytes and delay monocyte apoptosis, increasing the duration of inflammation [73].

Modifications of plasma proteins, structural proteins and other macromolecules are enhanced in diabetes not only due to increased glycation (secondary to increased glucose concentrations), but also due to oxidative stress that occurs during the course of the disease and may be a sign of noncomplicated DM. The combined effects of glycation and oxidation can accelerate the development of accompanying pathologies in DM. While glucose itself contains a carbonyl group that participates in the initial glycation reaction, the most important and reactive carbonyls are formed as a result of oxidation reactions that damage either carbohydrates (including glucose itself) or lipids. The resulting intermediates containing carbonyl then modify the proteins, giving the products of "glycoxidation" and "lipooxidation", respectively. This common pathway of glucose- and lipid-mediated stress is the foundation of the carbonyl stress hypothesis [74].

AGE are formed endogenously even in a healthy body, but recent studies have shown that diet is an important exogenous source of AGE $[75,76]$. Since glycation targets are free amino groups, potentially any protein can be modified, and each tissue can accumulate glycotoxins. In terms of the duration of AGE accumulation, 
long-lived proteins are the most important to study: these are the components of the extracellular matrix (collagen, laminin and elastin), lens protein $\alpha$-crystallin, cartilage, hemoglobin [58, 68]. For example, currently, glucose and glycated hemoglobin Alc (HbAlc) are standard biomarkers for diabetes monitoring, but $\mathrm{HbAlc}$ is a representative indicator for glycemic data for 23 previous months and is not adequate for monitoring therapy, whereas glucose levels can change significantly even during the day and can disorient the patient and even the doctor in gestational diabetes of mild and moderate severity [57]. Moreover, under certain conditions, the measurement of HbAlc is unreliable, in particular, for patients with modified erythrocytes or renal insufficiency $[77,78]$. Thus, there is a need for an intermediate biomarker that can be effectively used to monitor the glycemic status of patients. Such a biomarker can be albumin, which has a relatively short halfrenewal period (20-21 days). Albumin, the amount of which significantly exceeds the amount of other plasma proteins, is subject to glycation in the first place and allows predicting the risk of diabetes even in the case of euglycemia [79]. One of the main reagents found in vivo in adducts with albumin is carboxymethyl lysine (CML). Also glyoxal (GO), methylglyoxal (MG) and 3-deoxyglucosone (3-DG) [58,80] should be mentioned.

As it has been already mentioned, albumin is synthesized and enters the bloodstream in the form of a non-glycosylated protein, but over time, glycation of a certain part of albumin molecules occurs in the blood plasma of even a healthy person, which can affect its structural and functional characteristics [81, 82]. According to some estimates, from 10 to $18 \%$ of circulating proteins in normoglycemic blood are glycated in vivo, whereas in diabetics it reaches $40 \%$ [57, 83]. A comparative analysis of the ability of various sugars to interact with bovine albumin (BSA) in vitro showed that d-galactose is more reactive than d-glucose or d-lactose, whereas only conjugates of albumin with lactose were recognized by specific lectins [84]. To date, more than 60 human albumin glycation sites have been identified. Lys256 and Lys420 turned out to be the most accessible for conjugation, although Lys 525 is considered the most reactive in $\operatorname{HSA}[85,86]$.
In addition to lysine, arginine and histidine are the most reactive amino acid residues [58]. Oxidized albumin is more easily glycated, even at a physiological glucose concentration $(5 \mathrm{mM})$ [83]. The accumulation of AGE changes the structure and function of proteins, turning them into potential targets of the immune system, which can result in the production of autoantibodies against AGE. Albumin is not an exception, and it was shown that antibodies against albumin were found in the blood of patients with atherosclerotic vascular damage and signs of DM [87]. Moreover, IgG and IgA autoantibodies to HSA may have diagnostic significance in autoimmune bullous dermatoses (AIBD), despite the fact that dermal autoantigens have not yet been identified [88]. The phospho-p38 signaling pathway associated with DNA damage is a potential target for the treatment of patients with AIBD-positive serum autoantibodies to HSA.

Glycated albumin is used both for diagnostic purposes and for experimental study of systemic effects of AGE, many of which are mediated by $\mathrm{NF}-\kappa \mathrm{B}$, a universal transcription factor controlling the expression of immune response, apoptosis and cell cycle genes [89]. As it was already mentioned, plasma glucose and HbAlc are presently recognized as markers of DM. An alternative to HbA1c as a marker of diabetes mellitus has become fructosamine, which plays an increasingly important role in the diagnosis of this disease and is a measure of glycation of circulating proteins, among which albumin is the principal one, from the point of view of accessibility and assessment of the scale of observed changes [56]. Plasma albumin gradually displaces HbAlc during glycemic monitoring of patients with DM [77]. However, the accuracy of determining the degree of hyperglycemia by fructosamine is relatively low, not only because different proteins interact differently with glucose and other sugars, but also because bilirubin, uric acid and number of other low-molecular compounds contribute to the error of the method. Other disadvantages of the test include the lack of a generally accepted standard and even its low availability [90]. It cannot be said that various methods for determining glycated albumin are simple and accessible: we note here ion-exchange high-performance liquid 
chromatography, boronate affinity chromatography, immunoassays (radioimmunoanalysis and enzyme immunoassay), colorimetric method with thiobarbituric acid, and enzymatic methods using proteinase and ketamine oxidase. In recent years, the most popular enzymatic method "Lucica GA-LR" (Asahi Kasei Pharma Corporation, Japan), which has high reproducibility, accuracy and good correlation with A1C [90]. A test system on an indicator strip has been developed to measure the proportion of glycated albumin from total serum albumin. Aptamers with gold nanoparticles were used for colorimetric measurements. Both glycated and non-glycated albumin can be measured in the corresponding physiological concentration ranges-from 50 to 300 microns with a detection limit (LoD) of 6.5 microns for glycated albumin and from 500 to 750 microns with a LoD of 21 microns for non-glycated albumin [57].

The advantage of measuring of glycated albu$\mathrm{min}$ in clinical practice is its universality both as a mediator of inflammation and as a marker of hyperglycemia. A deeper understanding of the role of glycated albumin may lead to its acceptance as an independent marker of the inflammatory process [91]. Glycated albumin makes it possible to predict the risk of death in dialysis patients with diabetes mellitus [77], and in combination with hsCRP maximizes the accuracy of predicting cardiovascular diseases, especially those associated with left ventricular hypertrophy in patients with diabetic chronic kidney disease [78]. It should be particularly noted that glycated albumin can be transformed into amyloid fibrils that are rich in $\beta$-sheets [92].

As in the case of the effect of Cys34 oxidation on the binding activity of Sudlow sites, data on the effect of glycation on the antioxidant properties of albumin are contradictory [39, 93-95], which may be due to interspecies differences, the nature and concentration of carbohydrates involved in the reaction (glucose, methylglyoxal), incubation conditions with monosaccharides. Of particular interest are the differences between human and bovine albumin: glycation of HSA sharply reduces its antioxidant activity, while glycation of BSA slightly enhances its antioxidant properties. These data correlate with the results of computational experiments aimed at studying the effect of the redox status of HSA and BSA on their binding and esterase activity with respect to paraoxone [26, 96]. From the point of view of evolutionary and comparative biochemistry/physiology, the following fact seems to be important: the concentration of glucose in the blood plasma of birds is 1.52 times higher than in mammals of similar mass (this phenomenon is called benign hyperglycemia), however, avian albumin (for example, Chicken Serum Albumin, CSA) is glycated to a lesser extent than BSA, even when in vitro experiments albumins were exposed to increasing glucose concentrations up to $500 \mathrm{mM}$ [97]. Analysis of protein structures suggests that the relative resistance of CSA to glycation may be associated with fewer lysine residues and variations in protein stacking that protect lysine residues from interaction with plasma glucose. A comparative analysis of the reconstructed albumin sequences indicates that the ancestor of birds had 6-8 fewer lysine residues in the albumin molecule compared to mammalian albumin [97]. Benign hyperglycemia is a common physiological feature of birds, and the development of mechanisms of resistance to albumin glycation seems to have been inextricably linked with their evolution. It is believed that the development of benign hyperglycemia in birds corresponded with a radical rearrangement of the genome, in which the loss of important genes happened, including the gene encoding GLUT4-a carrier responsible for insulin-dependent glucose transport in insulin-sensitive cells of other vertebrates. This loss apparently led to remodeling of the insulin-dependent signaling pathway in avian tissues [98].

\section{INTERACTION OF ALBUMIN WITH ENDOTHELIAL CELLS: GLYCOCALYX, TRANSCYTOSIS AND CD36 GLYCOPROTEIN}

AGE causes multiple metabolic disorders in the vascular wall and can lead to endothelial dysfunction. Since a significant part of AGE is represented by glycated albumin, it is important to consider the features of the interaction of albumin with the vascular endothelium. Albumin interacts with endothelial cells (EC) through extracellular molecular agents, among which there are recep- 
tors, but most of them are combined into glycocalyx, which is a dynamic and heterogeneous "layer" between EC membranes, on the one hand, and blood components (plasma and blood cells), on the other hand. The endothelial glycocalyx is a layer of glycoproteins associated with EC membranes, which holds from 700 to $1000 \mathrm{~mL}$ of practically non-circulating plasma volume in the human body. This intravascular layer maintains its own colloidal osmotic (oncotic) pressure (COP) due to the plasma proteins contained in it (primarily albumin), which are retained inside the endothelial glycocalyx layer (EGL). Consequently, it has a higher COP than circulating plasma [99]. According to some estimates, EGL provides approximately $60 \%$ of intravascular COP [100]. Structurally, EGL is a negatively charged gel-like layer comprising oligosaccharide and polysaccharide chains of glycosaminoglycans (heparan sulfate, chondroitin sulfate, dermatan sulfate, keratan sulfate, hyaluronan), which are covalently bound to glycoproteins and proteoglycans, both transmembrane (antithrombin III, integrins, selectins, syndecans, glypicans) and soluble (perlecan, biglican, versican, decorin, mimecan). EGL has a thickness from 0.1 to 4.5 microns, depending on the localization and size of the vessel, and serves as a kind of reservoir of proteins and polysaccharides, such as antithrombin III and heparan sulfate [99].

The intact EGL maintains separation between the circulating plasma and the vascular endothelium, creating an "exclusion zone" that prevents blood cells from contacting the EC surface. In the presence of intact EGL, water and electrolytes freely pass first through this layer, and then beyond the EC through the intercellular gaps. This "exclusion zone" also prevents contact with the endothelium of high-molecular colloids weighing $>70 \mathrm{kDa}$. Albumin is practically the only plasma protein that easily moves between blood plasma and EGL due to the selective permeability of EGL for natural colloids with a molecular weight of $<70 \mathrm{kDa}$ [101].

The molecular radius of albumin hinders its passage between neighboring cells of an intact endothelial monolayer, which limits paracellular diffusion to molecules smaller than 3-5 nm [102-104]. However, the detection of albumin in interstitial and lymphatic fluids (up to $40-60 \%$ of the plasma level) indicates that the protein is able to leave the lumen of microvessels even in the absence of inflammation [105, 106]. It was shown in the work of Palade et al. [107] that albumin which was injected into the bloodstream of animals was later detected in the intracellular vesicles of the capillary endothelium; in some cases, these vesicles got free the albumin into the interstitium, although there was never a rupture of interendothelial contacts. Such vesicular transport is known as transcytosis and is mediated by caveoles; knockdown or deficiency of caveolin-1, without which caveoles cannot exist, averts transcytosis of albumin [108, 109]. Thus, albumin transcytosis is the main way of albumin transfer from the bloodstream to the interstitium in physiological conditions [107]. According to the important role of albumin as a vehicle for medicinal and toxic substances, the relevance of studying the kinetics and mechanisms of albumin transcytosis in blood vessels can hardly be overestimated [110]. It is known little about the regulation of transendothelial albumin transport, which is partly due to technical difficulties in its study. Thus, when they measure the permeability of the endothelium by cultured cells, there were some difficulties with separation of the contribution of paracellular leakage from true transcytosis [111]. A more serious reason for the poor study of transcytosis of albumin by EC is associated with the uncertainty of the physiological significance of this process. Mice with caveolin-1 deficiency do not have caveols and demonstrate reduced endothelial internalization of albumin, but there is a compensatory increase in paracellular transport in these animals [112]. This model underlines the importance of transporting albumin outside the vascular bed, but does not give an answer about the physiological function of transcytosis. Taking into account the numerous fatty acid binding sites [113], it can be assumed that transcytosis of albumin is important for the regulated transfer of circulating fatty acids to various tissues. In this regard, a long-established phenomenon seems to be important: albumin deficiency correlates with an increased level of circulating cholesterol and phospholipids [114, 115].

Most of the work related to the study of trans- 
cytosis was carried out on the lung endothelium, whose cells bind albumin through glycoprotein 60 (gp60) in caveoles and provide its transfer with the participation of tyrosine kinases [116, 117]. Transcytosis of albumin in the lungs is stimulated by thrombin, this process is associated with an increase in the activity of acidic sphingomyelinase, which promotes the synthesis of ceramide, caveolin-1 and its recruitment to the lipid rafts of the membrane; stimulation of albumin transcytosis by proinflammatory mediators may contribute to the leakage of alveolar protein in lung injury [118]. However, another mechanism of transcytosis is of great importance in the lungs, there is low-affinity absorption of albumin in the liquid phase by the type of pinocytosis [119]. Pinocytosis is a process of nonselective absorption by the cell of the liquid phase from the environment containing soluble substances, due to the lacing inside of small bubbles (endosomes) that merge with lysosomes [120].

For a long time, practically nothing was known about the transcytosis of albumin in other tissues. Taking into account the notable heterogeneity of the vascular endothelium in different organs [121], it could be assumed that there are different mechanisms of albumin transcytosis. This assumption was confirmed in a recent work by Raheel with co-authors: according to their data, transcytosis of albumin in the skin, unlike in the lungs, has kinetics of saturation, which indicates a receptor-mediated process [122]. It was found that for transcytosis of albumin through the endothelium of the microvessels of the dermis, a necessary and sufficient condition is the expression of CD36 glycoprotein, which is also known as a class 3B scavenger receptor (SR-B3), platelet membrane glycoprotein IV (GPIV), glycoprotein IIIb (GPIIIB), thrombospondin receptor, collagen receptor, fatty acid translocase (FAT) and even as the receptor of innate immunity [123]. When the ligand binds, CD36 triggers a signaling cascade that mediates a wide range of pro-inflammatory responses. For example, amyloid- $\beta 1-40$ $(\mathrm{A} \beta)$, interacting with $\mathrm{CD} 36$, activates the generation of superoxide anions by NADPH oxidase [124]. In acute lung injury, an increased level of ROS and intracellular calcium play a key role in the dysfunction of the endothelial barrier: the
$\mathrm{H}_{2} \mathrm{O}_{2}$-induced increase in $\left[\mathrm{Ca}^{2+}\right]_{\mathrm{i}}$ in the EC of the microvessels of the lungs is associated with the activation of TRPV4 (type 4 cationic vanilloid channels with transient receptor potential) saturation, and CD36 plays an important role in $\mathrm{H}_{2} \mathrm{O}_{2}$-mediated lung damage through CD36-dependent fixation of Fyn kinase (from Src-families) on the cell membrane to facilitate phosphorylation of TRPV4 [125].

CD36 glycoprotein is expressed on the surface of not only microvessels' EC, but also on the surface of platelets, monocytes, smooth muscle cells, cardiomyocytes and a number of other cells, though it is absent in the lymphatic vessels of the dermis [126]. Despite its widespread distribution, CD36 remained a rather mysterious protein for a long time. It was gradually established that CD36 can influence cellular responses due to interaction with various ligands, in particular, with thrombospondin-1, oxidized LDL and long-chain fatty acids [127, 128]. Currently, CD36 is considered to be the main membrane protein involved in lipid homeostasis of the body. CD36 acts in agreement with membrane and cytoplasmic fatty acid binding proteins. The rate of absorption of fatty acids depends on the presence of CD36 on the cell surface, which is regulated by subcellular vesicular recirculation of $\mathrm{CD} 36$ from endosomes to the plasma membrane [129]. However, non-esterified fatty acids cannot circulate freely in plasma, they are bound to albumin [130], which has seven fatty acid binding sites [131]. Interaction with CD36 is associated with activation of Src-family kinases and mitogen-activated protein kinases, as well as with the participation of Rho-GTPases and transcription factor $N F-\kappa B$ [132]. Still to be found out does albumin binding and transcytosis require the involvement of these or other signaling pathways.

In mice selectively deficient in endothelial CD36, a reduced level of subcutaneous fat was noted, despite the fact that the level of circulating lipids was comparable to that of control animals, and representatives of both groups had a similar body weight [122]. This is consistent with a defect in the transport or metabolism of lipids at the border between the endothelium and the skin. According to this hypothesis, analbuminemic rats exhibit intense hypercholesterolemia [133], and patients with congenital albumin deficiency 
demonstrate elevated serum concentrations of cholesterol and phospholipids, which temporarily return to normal after intravenous albumin infusions [114, 115]. Deficit of CD36 or mutations in it have not previously been associated with the skin phenotype [134], but this is due to the fact that previous studies have investigated the effect of CD36 deficiency throughout the body, and not in deletion specific to EC. After the discovery of the role of CD36 in the skin, the question arises about the role of CD36 in the endothelium of the microvessels of the lungs. Although it does not mediate albumin transcytosis, there is evidence that the endothelial CD36 of the lungs is involved in the reaction to inhaled pollutants [135] or to infection [136].

However, CD36 is not an exclusive mediator of the effect of fatty acids on EC. In the absence or lack of albumin, inflammation may occur as a result of their interaction with Toll-like receptors, and not as a consequence of absorption through CD36 [137]. Thus, palmitate, which is not associated with albumin, activates inflammatory pathways in microvessels, increases the generation and/or expression of IL-6, IL-8, TLR2 and ICAM-1 in them, disrupts insulin transport and promotes monocyte transmigration. Inhibition of CD36 does not affect palmitate-induced expression of adhesion molecules; at the same time, suppression of signaling through TLR4 to NF- $\mathrm{B}$ reduces palmitate-induced expression of ICAM-1 [137]. Such signaling switching options are important for understanding the significance of albumin in both the prevention and development of diseases of the cardiovascular system.

\section{INTERACTION OF GLYCATED ALBUMIN WITH ENDOTHELIUM}

In diabetic patients, the level of glycated albumin is more than $70 \mu \mathrm{M}$; it is one of the initiators of EC apoptosis [138]. The likelihood of atherosclerotic plaque formation in the carotid artery in patients with type $2 \mathrm{DM}$ correlates with an increased level of glycated albumin and a decreased level of endothelial progenitors (CD34+/133+/309+) [139]. Interestingly, as the plaques formed, the level of glycated albumin decreased, as did the ratio of glycated albumin to glycated hemoglobin. This is partly due to the fact that in diabetes, aortic EC switch to a biosynthetic phenotype with an increased number of caveolae and increased (by about 20\%) transcytosis of glycated albumin. In EC culture, $25 \mathrm{mM}$ glucose causes an approximately 2.6-fold increase in pSTAT-3 and pERK1 and an approximately 1.8-fold increase in pERK2; exposure to glycated albumin $(5 \mu \mathrm{M})$ causes an approximately 4.3 -fold increase in pERK1/2 compared to $5 \mathrm{mM}$ glucose [140].

Glycated albumin induces the expression of procoagulant and inflammatory factors by EC $[141,142]$. At the same time, there is evidence that the increased level of von Willebrand factor in diabetics is due not to glycated albumin, but to the effect of mannose-specific lectins on the hydrocarbon determinants of EC [143]. However, it should be noted that glycated albumin was tested at low concentrations in the culture of human umbilical vein EC (HUVEC) (25-100 $\mu \mathrm{g} / \mathrm{mL}$ ), while physiologically much more active lectins (concanavalin A, ConA, and wheat germ agglutinin, WGA) were tested at not far lower concentrations $(4-16 \mu \mathrm{g} / \mathrm{mL})$.

In diabetes mellitus, many morphofunctional abnormalities of cells are mediated by auto- and paracrine TGF- $\beta$, which is induced by high levels of glucose in the environment and glycosylated proteins. For most cell types, TGF- $\beta$ is an inducer of apoptosis, which is mediated by Alk5, the type I TGF- $\beta$ receptor. In contrast, early diabetic microangiopathy is characterized by increased proliferation of EC. EC are unique in that they express a second type I TGF- $\beta$ receptor, Alk1, as well as the endoglin coreceptor, which increases the ligand's affinity for Alk1. In differentiated EC of healthy subjects, Alk1 and endoglin are constitutively expressed. However, incubation of EC with high glucose and glycated albumin in the medium induces Alk5 expression and increases TGF- $\beta$ secretion by a factor of 3 , without affecting Alk1 or endoglin levels. The "diabetic" environment accelerates cell proliferation, at least in part, due to TGF- $\beta /$ Alk1-smad $1 / 5$ and, probably, with the participation of VEGF, as well as promigratory MMP2 below Alk1. In addition, the activity of caspase- 3 is partially increased, which indicates an increase in apoptosis using the TGF- $\beta /$ Alk5- 
smad2/3 pathway. These data suggest pleiotropy of TGF- $\beta$ in EC, including proliferative effects (via Alk1-smad1/5) and pro-apoptotic signals (via Alk5-smad2/3) [144]. Among other proinflammatory cytokines whose synthesis induces glycosylated albumin, TNF- $\alpha$ should be mentioned [145]. IL-6 expression by EC is also increased when exposed to glycated albumin, but this increase can be prevented by angiotensin 1-7, a product of ACE2 activity [146].

Glycated albumin enhances the expression of RAGE against the background of shear stress [147] and increases the expression of adhesion molecules VCAM-1, ICAM-1, and E-selectin [148]. The expression of EC adhesion proteins (in particular, E-selectin, or CD62E) increases precisely when exposed to glycated albumin; this effect is not observed under the action of a heterogeneous mixture of AGE, which are formed as a result of non-enzymatic glycation and oxidation of proteins, lipids and nucleic acids [149]. Glycated albumin of patients with heart failure and high levels of glycation also increased the expression of adhesion molecules in HUVEC and enhanced adhesion of peripheral blood mononuclear cells to the EC [150]. It is well known that mononuclear cells are powerful generators of ROS, but what is especially important, the increase in the expression of adhesion molecules is mediated by the generation of ROS by NADPH oxidases of EC and signaling with the participation of kinases PKB-IKK and $\mathrm{JNK}$, transcription factors $\mathrm{NF}-\kappa \mathrm{B}$ and $\mathrm{AP}-1$. It was found that the generation of ROS is maximally expressed $4 \mathrm{~h}$ after the onset of exposure to glycated albumin and is accompanied by an increase in the expression of Nox4 and p22phox mRNA [151]. Endothelial NOX2 activation also contributes to dysfunction of the glomerular apparatus in insulin-dependent mice, decreasing the expression of the glomerular glycocalyx and causing morphofunctional changes in podocytes and mesangial cells; ultimately, this contributes to the development of diabetic nephropathy, one of the signs of which is albuminuria [152]. In addition to NOX4, another source of ROS under the action of glycated albumin on EC is uncoupled eNOS [153]. Glycated albumin can both enhance and weaken the activity of NO synthase, and both response variants were noted during the develop- ment of EC apoptosis under the action of glycated albumin [138, 154, 155]. This is consistent with the notion that oxidative stress plays a key role in endothelial damage in diabetes, and the degree of albumin glycation affects its intensity through a possible connection between NADPH oxidases, mitochondria, and other sources of ROS [156]. Recently, it has been shown that one of the important mediators of AGE-induced diabetic endothelial dysfunction is peroxidasin (PXDN), a member of the peroxidase family, which catalyzes the conversion of hydrogen peroxide to hypochlorous acid. It is believed that NOX2 is the main source of ROS upon exposure to AGE, while the action of $\mathrm{HOCl}$ leads to a weakening of eNOS phosphorylation at Ser1177 and a decrease in NO synthesis [157]. Another participant in the antioxidant defense of EC and the target of glycated albumin is intracellular paraoxonase-2 (PON2). Glycated albumin, as well as N-carboxymethyllysine (CML, the most famous representative of AGE), suppresses the expression and activity of PON2 in EC [158]. In addition, the effect of glycated albumin and CML on the endothelium leads to an increase in the level of endoplasmic reticulum stress markers GRP78 and IRE1 $\alpha$, as well as to an increase in the expression of proinflammatory cytokines MCP-1, IL-6, IL-8, adhesion proteins ICAM1 and VCAM1. On the other hand, an increase in the expression of PON2 leads to a decrease in the level of ROS and facilitates endothelial dysfunction caused by AGE [158].

\section{ROLE OF MODIFIED ALBUMIN IN THE PATHOGENESIS OF DISEASES}

Despite the availability of major proteins in general and albumin in particular, information about the mechanisms of albumin modification and the mechanisms of the effect of modified albumin on cells, tissues, and human health is insufficient, and the available data are often contradictory. The specificity of the pathogenesis of a particular organ is due to the fact that when the endothelium is damaged, the release of albumin outside the vascular bed goes out of control, that leads to a change in the biological activity of parenchyma cells. In addition, various blood cells can also serve as a target for AGE and glycated albumin, which, 
as a rule, aggravates the state of EC and causes disruption of the blood-tissue barriers. Thus, glycated albumin enhances the thrombogenic potential of platelets due to an increase in the number and sensitivity of receptors [159].

The pathogenic role of AGE and glycated albumin is best studied in obesity, diabetic polyneuropathy and nephropathy [58, 160, 161]. The SARS-CoV-2 coronavirus, which caused the COVID-19 pandemic, has stimulated research on the relationship between susceptibility to infection and a history of other diseases, including those listed above, one of the pathogenic factors of which is glycated albumin.

\section{Obesity}

Visceral fat is one of the main sources of proinflammatory cytokines due to activated macrophages, which are much more abundant in comparison with subcutaneous fat. This is primarily due to the accumulation of glycated albumin and increased expression of RAGE [160]. Among the cytokines, there are the molecules that interact with RAGE (S100ß and HMGB-1), as well as the molecules whose level increases upon activation of RAGE (MCP-1, IL-6, TNF $\alpha$, TGF- $\beta$, and a number of others). Chronic inflammation is maintained by constant recruitment of macrophages through RAGE-dependent expression of MCP-1 and further RAGE activation; this selfamplification loop is called the RAGE/MCP-1 axis [162]. Increased levels of AGE, the main of which is glycated albumin, fuels both oxidative stress and the AGE/RAGE axis, which in turn can increase inflammation in already inflamed tissue, thereby accelerating the progression of obesity. In addition, the adaptive functions of adipocytes are disrupted by other AGE receptors: for example, the capture and degradation of AGE by the CD36 scavenger leads to a decrease in the generation of leptin by adipocytes, which may contribute to the development of obesity [163].

\section{Diabetic polyneuropathy}

It was found that diabetic polyneuropathy (DPN) develops in all patients with type $1 \mathrm{DM}$ within 15 years and in $30 \%$ of patients with type 2 DM within 25 years [164]. A characteristic feature of DPN is EC hyperplasia and thickening of the basement membrane of endoneural capillaries and other microvessels. The mechanism of this phenomenon remains unclear. To what extent is it related to the polyol pathway of glucose metabolism in EC or to the effect of glycated albumin on AGE receptors? One of the molecular pathogenetic factors of DPN is a decrease in the synthesis of claudin-5, which leads to disruption of the barrier function of the endothelium and edema of the nerve fiber. AGE reduce the amount of claudin-5 indirectly, by increasing the autocrine secretion of endothelial growth factor (VEGF) by EC forming the blood-nerve barrier (BNB) [161]. In addition, pericytes play an important role in the formation and maintenance of the basement membrane of the BNB. They produce fibronectin and type IV collagen, as well as a tissue inhibitor of metalloprotease-1 (TIMP-1), which prevents degradation of the basement membrane. It turned out that during hyperglycemia, AGE accumulate in pericytes, increasing the autocrine secretion of VEGF and TGF- $\beta$. VEGF and TGF- $\beta$ signaling enhances the production of fibronectin and type IV collagen, which leads to a thickening of the basement membrane [161].

Interestingly, treatment of hyperglycemia reduces the incidence of DPN by $60-70 \%$ in patients with type $1 \mathrm{DM}$ [165] and only by 5-7\% in patients with type 2 DM [166]. Moreover, at least $40 \%$ of patients with type 2 DM develop DPN even with glucose control [167]. The data on the role of modified (glycated and/or oxidized) albumin in the pathogenesis of DPN are insufficient to seriously discuss the prospects for the development of effective therapy.

\section{Diabetic nephropathy}

Each kidney contains approximately 1 million nephrons. Each nephron consists of a glomerulus and tubules. Glomeruli are composed of four types of cells: parietal epithelium, glomerular endothelial cells (GEC), podocytes (visceral epithelial cells), and mesangial cells. Endothelium and podocytes share a common extracellular matrix called glomerular basement membrane (GBM). GEC and their openings are covered with endothelial glycocalyx. Podocytes have processes with slit diaphragms that surround the outer part of the capillaries. GEC with endothelial glycocalyx, 
GBM and podocytes constitute the renal filtration barrier, or glomerular filtration barrier. In diabetes, the exchange of signals between cells is disturbed in the filtration barrier, while the primary increase in the synthesis of vascular endothelial growth factor A (VEGFA) by podocytes, observed in the early stages, is replaced by a decrease in VEGF synthesis during the progression of the disease. There is also a loss of interaction between angiopoietin-1 (Angpt1) and the tyrosine protein kinase receptor (Tie2), and the production of activated protein $\mathrm{C}$ (APC) in the glomeruli is reduced due to suppression of thrombomodulin expression. A decrease in the functional activity of APC affects the permeability of the glomerular capillary wall and enhances apoptosis of glomerular EC and podocytes. Metabolic changes associated with DM, along with the activation of the renin-angiotensin-aldosterone system (RAAS), cause the generation of ROS and RNS (nitric oxide, nitrogen dioxide, and peroxynitrite) in glomerular EC. The activity of endothelin-1 (Edn1) in DM increases oxidative stress, causes depletion of endothelial nitric oxide (NO) and degradation of endothelial glycocalyx [168].

However, glomerular endothelial dysfunction is characterized not only by damage of the endothelial glycocalyx and oxidative stress in the EC, but also by the endothelial-mesenchymal transition (EndMT) [169]. EndMT is the process by which EC lose their endothelial phenotype (for example, a reduced expression of endothelial cell markers CD31 and CD144) and endothelial-specific functional characteristics (athrombogenicity, barrier functions, etc.). The decrease in the expression of endothelial markers is accompanied by an increase in the expression of mesenchymal markers such as $\alpha$-smooth muscle actin ( $\alpha$ SMA) and fibroblast specific protein 1 (FSP-1); in addition, the synthesis of extracellular matrix proteins (ECM) increases [170]. EndMT promotes the development of fibrosis and is observed in diseases of a wide variety of organs, including cancer [171-173]. EndMT is also observed in the glomeruli of patients with diabetic nephropathy, as evidenced by the co-expression of endothelial and mesenchymal markers [174]. Hyperglycemia, AGE, glycated albumin, hypoxia and a number of other factors cause glomerular endothelial dys- function, which is characterized by damage to the endothelial glycocalyx, oxidative stress, inflammatory phenotype of EC and EndMT; this leads to proteinuria, damage or loss of podocytes, activation of mesangial cells, and ultimately glomerulosclerosis. An additional pathway of kidney damage in DM is the transdifferentiation of renal tubular cells into myofibloblasts. This occurs when RAGE is activated, which induces the expression of TGF- $\beta$ and other cytokines that mediate this transdifferentiation [175]. Activation of $\mathrm{NF}-\kappa \mathrm{B}$, along with RAGE amplification and cytokine expression, causes the activation of gene $Z E B 2$ encoding the ZEB2 protein. Transcription factors of the ZEB family lead to EndMT, impairment of podocyte adhesion, detachment of the basement membrane and the loss of podocytes in the glomeruli [68]. Activation of PKC, TGF- $\beta$ and gene expression in mesangial cells, along with a similar effect on the EC of the glomerular apparatus, is also a cause of diabetic nephropathy, especially in type 1 DM [176, 177]. It should be noted that EndMT is not an irreversible process; the possibility of reverse reprogramming of transformed ECs has been shown [170], and EndMT is also controlled by autophagy [178, 179].

\section{COVID-19}

In addition to numerous observations indicating albumin modifications and decrease in its level in various diseases accompanied by inflammatory processes, including in many patients with coronavirus infection [180], the cytokine storm observed in patients with COVID-19 occurs partially due to an increased level of oxidized albumin [181]. At the same time, RAGE plays an important role in the pathogenesis of lung diseases such as fibrosis, pneumonia and acute respiratory distress syndrome (ARDS). Overexpression or hyperactivation of RAGE enhances the negative effect of renin-angiotensin system (RAS) mediators on chronic diseases, which are the main risk factors for coronavirus infection: diabetes, kidney and cardiovascular diseases [182]. After recognition and binding of the spike protein of the coronavirus by the angiotensin-converting enzyme type 2 (ACE2), SARS-CoV-2 enters the cell, which leads to suppression of ACE2 regulation and an increase in angiotensin II (AngII). 
Infected cells undergo pyroptosis and release of damage associated molecular patterns (DAMP), including HMGB1. DAMP, cytokines and RAGE ligands lead to increased expression of RAGE by $\mathrm{NF}-\kappa \mathrm{B}$. Under these conditions, RAGE induces further downregulation of ACE2, upregulates the expression of AT1R (type 1 receptor of AngII), and transactivates with AT1R, enhancing the pathogenetic effects of the ACE/ AngII/AT1R axis. At the same time, the interaction of AngII with AT1R induces the activation of $\mathrm{NF}-\kappa \mathrm{B}$ and the release of RAGE ligands; a vicious circle is formed. Connection of RAGE with RAS effectors promotes cytokine storm development in macrophages and splenocytes; causes endothelial dysfunction by increasing capillary permeability and release of components of DAMP; enhances the production of ROS and the formation of atherosclerotic plaques; increases the risk of thrombosis by inducing the formation and release of extracellular traps by neutrophils (NET), followed by platelet aggregation; cause muscle wasting, stimulating apoptosis, increasing protein degradation and decreasing protein synthesis. The combined effect of RAGE and AT1R occurs in the vessels and parenchyma of the lungs, brain, heart and kidneys, in the cells of the immune system, causing irreversible damage to many organs [183]. In this case, the question of what is primary (cause) and what is secondary (consequence) not only has the right to exist, but deserves the most serious attitude on the part of scientists and physicians.

\section{The role of albumin in epileptogenesis}

Recent findings strongly suggest that AGE are the main contributors to brain microvascular damage and disruption of the blood-brain barrier (BBB) [184]. Interactions between the BBB, cerebral blood vessels, neurons, astrocytes, microglia and pericytes form a dynamic functional neurovascular unit. Damage to the cerebral cortex as a result of trauma, intoxication, ischemia or infection can lead to the development of post-traumatic epilepsy (PTE), one of the most common neurological disorders, the pathogenesis of which is closely related to the violation of the BBB integrity [123, 185]. In turn, it leads to leakage of plasma components into the brain parenchyma and increased excitability of neurons. First, the levels of $\mathrm{K}^{+}$and glutamate rise, then coupled mechanisms are triggered: extravasated albumin is absorbed by astrocytes through TGF- $\beta R$ and leads to Smad2-mediated suppression of the Kir4.1 potassium channel, while astrocytic TNF- $\alpha$ initiates a decrease in the expression of glutamate transporter EAAT-2. Both mechanisms exacerbate primary neuronal overactivity due to impaired buffering of $\mathrm{K}^{+}$and glutamate by astrocytes, resulting in extracellular potassium accumulation, relief of NMDA-mediated hyperexcitability and, ultimately, epileptiform activity [186-188]. It should be noted that the same signaling pathway is activated in aging people with BBB dysfunction [189]. Nowadays there are no funds to identify patients at risk of developing PTE or to prevent its development. Seizures can occur months or years after stroke, do not respond to anticonvulsants in more than a third of patients, and are often associated with significant neuropsychiatric illness [190]. An increased concentration of albumin causes an increase of $\left[\mathrm{Ca}^{2+}\right]$ due to activation of inositol-1,4,5-triphosphate (IP3) signaling pathway; in addition, albumin induces DNA synthesis. These processes are partially blocked by heparin and TGF- $\beta$ antagonists [191]. Thus, the use of SJN2511, a specific inhibitor of the ALK5/TGF- $\beta$ astrocytic pathway, prevents excitatory synaptogenesis and albumin-induced epilepsy [190]. At the same time, the use of nonspecific drugs, such as losartan (AT1 antagonist), also prevents BBB impairment and the development of epileptogenesis [185]. However, the question of the differences in the affinity of unmodified and modified albumin for cytokine receptors of the brain parenchyma remains unexplored. The development of specific and nonspecific drugs for PTE therapy taking into account the pathogenetic role of albumin is one of the most pressing problems of modern pharmacology.

\section{CONCLUSION: INTEGRATIVE PROPERTIES OF ALBUMIN IN DIAGNOSTICS AND THERAPY}

Plasma or serum albumin has been a classic marker of nutritional status for many years, espe- 
cially for protein foods. Albumin level less than $35 \mathrm{~g} / \mathrm{L}$ defined as hypoalbuminemia. Recently, low albumin level is increasingly considered as a risk factor and predictor of morbidity/mortality, regardless of gender, age, comorbidities and all kinds of gene polymorphisms [192-194]. From the point of view of diagnostics, the level of albumin in blood plasma and in urine characterizes not just the level of one of the proteins, but, in fact, its integrative characteristics in terms of assessing the state of the whole organism, since it reflects the protein-synthesizing function of the liver (hence its role as negative acute phase protein [195]) and the functional state of the vascular endothelium, which determines the integrity of the blood-tissue barriers. The relationship between the integrity of the endothelium and the level of albumin in urine is the most studied phenomenon in medical practice, indicating primarily kidney pathology, but also the state of other components of the blood and cardiovascular system [196-198]. Among these components, the cerebral vascular endothelium is the most interesting, because there is the brain parenchyma on the other side of the barrier, whose functional units have proven to be extremely vulnerable to the action of albumin due to the presence on astrocytes of a receptor, until recently thought to be specific to TGF- $\beta$, one of the minor cytokine proteins that regulate cell differentiation and apoptosis [190, 191]. At the time when cytokine regulation research began or even flourished, this was hard even to imagine: a common receptor to proteins whose concentration difference in blood serum is more than 9 (!) orders of magnitude. The difference in affinity to the receptor is more than offset by the potential superiority in the number of albumin molecules that can access astrocyte receptors when the integrity of the BBB is compromised. In this regard, of great interest are the cytotoxic characteristics of redox-modified and glycated albumin not only in relation to the EC of blood vessels, but also in relation to the cytokine receptors of astrocytes.

A large-scale search for new diagnostic indicators using modern metabolomics technologies has made it possible to single out from a huge list of only four simple indicators of blood plasma, which allow to accurately assess the state of human health and predict the likelihood of death for patients, regardless of their age, gender and the nature of existing or past diseases; among these four indicators, the level of albumin in terms of the degree of contribution to the integral assessment was in second place after orosomucoid (alpha-1-acid glycoprotein) [193]. A similar result was obtained in the study of patients in intensive care units: the use of a simple ratio of positive (C-reactive protein) and negative (albumin) acute phase proteins can significantly increase the accuracy of assessing the risk of death [199]. A structurally similar ratio, but with markers of muscle fiber damage in the numerator (creatine kinase or myoglobin), significantly increases the correlation of biochemical indicators with functional and physiological (instrumental) indicators [200]. The urine albumin/creatinine ratio is one of the most sensitive indicators of glomerular renal dysfunction and hypertension in patients with high-risk neuroblastoma treated with myeloablative regimens [201]. And already during the pandemic of coronavirus infection, it was found that there was an inverse correlation between mortality from COVID-19 and blood albumin concentration [202]. The authors of the study suggested that this association might be related to the anticoagulant and antioxidant properties of albumin.

Competent application of regression analysis methods makes it possible to increase the sensitivity and specificity of diagnosing diabetic complications through the use of "internal" indicators of albumin, such as the ratio of its reduced and oxidized forms [203]. The ratio of oxidized albumin to total albumin can increase in liver diseases, diabetes, cardiovascular diseases, which leads to bacterial or viral infections. And again, during the pandemic, it was found that, due to the induction of a cytokine storm, the level of oxidized albumin in the blood of patients with COVID-19 can be a positive predictor of mortality [181].

However, albumin can serve not only as a biomarker of the severity of various pathologies, but also as a means of therapy. Due to its critical physiological role, human albumin is in the greatest demand among other biopharmaceuticals. Currently, the annual demand for HSA worldwide is estimated at about 500 tons [204]. Injec- 
tions of a 5\% albumin solution (isooncotic solution) are prescribed if necessary to increase the intravascular volume, injections of a $20-25 \%$ albumin solution (hyperoncotic solution) are prescribed to restore the colloid-osmotic (oncotic) pressure and maintain the fluid balance between the intravascular and extravascular compartments [205]. Clinical indications for the use of a 4-5\% albumin solution are hypovolemic shock, acute liver failure, cardiopulmonary bypass [206]. Indications for use of a $20-25 \%$ solution are not so evident [207]. It should be borne in mind that routine correction of hypoalbuminemia in seriously ill patients is not recommended, and its use in sepsis and septic shock remains controversial. Continuous infusion of $4 \%$ albumin solution to ICU patients reduces the risk of nosocomial infections [208]. According to the data obtained, albumin reduces the oxidized form of vasostatin-1 and thereby restores its antimicrobial properties. Albumin can be used to deliver organosulfur compounds to melanoma cells to inhibit melanin synthesis [209]. The ability of albumin to bind water can be used in the treatment of organophosphate poisoning. A decrease in glycocalyx leads to a decrease in oncotic pressure and hypovolemia, so that appropriate compensation could become one of the therapeutic factors in acute organophosphate poisoning in order to reduce the risk of death and prevent delayed pathology. Indeed, cases of successful use of fresh frozen plasma in the treatment of the intermediate syndrome, which is one of the possible consequences of poisoning with organophosphates, have been described [210].

At the same time, the introduction of albumin in some situations can be dangerous. Conditions in which the use of albumin is contraindicated due to the risk of acute circulatory overload are cardiac and renal failure, acute or chronic pancreatitis, pulmonary edema, or severe anemia. Also, the use of albumin is not recommended for the conditions such as ascites responsive to diuretics, non-hemorrhagic shock, hypoalbuminemia without edema or acute hypotension, malnutrition, open wounds, acute normovolemic hemodilution in surgery, protein loss due to enteropathy or malabsorption. In addition, the use of albumin can be life-threatening for patients with cerebral ischemia and trau- matic brain injury [205, 211].

From a physiological point of view, the simplest and most natural way of influencing the level and properties of albumin is the so-called "functional nutrition", i.e. the use of such products in food and the use of such methods of processing them, which would maximally preserve the amount and useful qualities of the nutraceuticals contained in them. These nutraceuticals, in turn, would have a positive effect on the intestinal microflora and on the functional state of the liver, where partial metabolism of nutraceuticals and albumin synthesis occurs, as well as on the state of albumin in the blood plasma, because many polyphenols and other nutraceuticals are bound and transported in the systemic circulation mainly by albumin [212], changing its conformation and competing with other ligands, including fatty acids and AGE. The relationship between glycated albumin and other dietary AGE, on the one hand, and gut microbiota, on the other, has recently become the subject of research [213]. The need for the development of standardized methods for determining the rate of consumption of AGE is rightly indicated. Numerous studies have shown that polyphenols largely determine the number, composition and condition of intestinal bacteria, which, in turn, modulate neurological diseases [214]. Polyphenols have not only antioxidant properties, but also the ability to protect proteins from glycation (antiglycating ability). The consumption of polyphenols with food causes an increase in the peripheral blood concentration of phenolic acids, of which the major (dominant) is 3-hydroxyphenylacetic acid (up to $338 \mu \mathrm{M}$ ), while the concentrations of other phenolic acids are in the range from $13 \mathrm{nM}$ to $200 \mu \mathrm{M}$. In an in vitro experiment, it was shown that pre-incubation of BSA with various phenolic acids and subsequent glycoxidation of albumin (5-10 $\mathrm{mM}$ glucose in combination with $10 \mathrm{nM}$ $\mathrm{H}_{2} \mathrm{O}_{2}$ ) significantly reduces the concentration of fructosamine [215]. Common polyphenols that can reduce albumin glycation include chrysin and luteolin, structurally related flavone aglycones found in broccoli, chili peppers, celery, rosemary, and honey [80]. The anticarcinogenic and cardioprotective properties of luteolin and chrysin are known, in particular, due to their ability to neutralize ROS, suppress the expression of cyclooxy- 
genase- 2 and the formation of prostaglandin E2 [216]. The polyphenol-rich extract of the medicinal plant Doratoxylon apetalum proved to be an effective antioxidant for protecting EC by reducing the level of ROS-hydrogen peroxide and superoxide [215]. In addition to polyphenols, garlic extract also inhibits the formation of AGE, including glycated albumin [217].

It is believed that aging-related conjugation of oxidative and carbonyl stress (gluco-oxidative stress) with the formation of AGE generates neoepitopes on blood proteins, promoting the production of autoantibodies in the elderly, especially in smokers. The use of natural products with antioxidant nutraceuticals reduces the manifestation of age-related pathophysiological changes.

The mechanism of the protective action of polyphenols is not fully understood, but it is assumed that polyphenols interact non-covalently with aromatic amino acid residues of albumin; this hydrophobic interaction promotes the remodeling of mature AGE-modified amyloid fibrils and transforms the secondary structure into a helical or disordered helical conformation [92]. Chrysin and luteolin inhibit the formation of albumin fibrils. The docking results showed that both flavonoids non-covalently interact with various amino acid residues of the IIA subdomain, including lysines and arginines prone to glycation, and additionally stabilize the HSA structure, which explains the mechanism of their action as antiglycating and antifibrillating agents [80]. It is assumed that polyphenolic compounds have a pleiotropic effect and prevent glycation at different levels: by regulating glucose metabolism, chelating metals, trapping intermediate dicarbonyl compounds, influencing cell insulin resistance, and finally, by activating the signaling pathway of the insulin-like growth factor receptor [218].

Thus, the characteristics of albumin revealed in recent years indicate that this major blood plasma protein, which until recently was assigned the "modest" role of an osmotically active component, is in fact a molecular "core", a link between various tissues and organs, indicating health of the whole organism and in many respects determines this health. Modern diagnostics, the pathogenesis of various diseases and the development of thera- peutic agents are currently unthinkable without a comprehensive account of the physicochemical, evolutionary-genetic, and physiological-biochemical characteristics of albumin.

\section{AUTHOR CONTRIBUTIONS}

Conceptualization (N.V.G.), data collection (D.A.B., P.A.V and N.V.G.), manuscript preparation and editing (D.A.B., P.A.V. and N.V.G.).

\section{FUNDING}

These studies were supported by the State assignment AAAA-A18-118012290142-9.

\section{CONFLICT OF INTERESTS}

The authors declare no obvious and potential conflicts of interest related to the publication of this article.

\section{REFERENCES}

1. Peters T (1995) All about albumin: biochemistry, genetics and medical applications. Acad Press, London.

2. Raoufinia R, Mota A, Keyhanvar N, Safari F, Shamekhi S, Abdolalizadeh J (2016) Overview of albumin and its purification methods. Adv Pharm Bull 6:495-507.

3. Mozzi A, Forni D, Cagliani R, Pozzoli U, Vertemara J, Bresolin N, Sironi M (2014) Albuminoid genes: Evolving at the interface of dispensability and selection. Genome Biol Evol 6:2983-2997. https://doi.org/10.1093/gbe/evu235

4. Li S, Cao Y, Geng F (2017) Genome-Wide Identification and Comparative Analysis of Albumin Family in Vertebrates. Evol Bioinform 13:1-6. https://doi.org/10.1177/1176934317716089

5. Haefliger DN, Moskaitis JE, Schoenberg DR, Wahli W (1989) Amphibian albumins as members of the albumin, alpha-fetoprotein, vitamin D-binding protein multigene family. J Mol Evol 29:344354. https://doi.org/10.1007/BF02103621

6. Lichenstein HS, Lyons DE, Wurfel MM, Johnson DA, McGinley MD, Leidli JC, Trollinger DB, Mayer JP, Wright SD, Zukowski MM (1994) Afamin is a new member of the albumin, alpha-fetoprotein, and vitamin D-binding protein gene family. J Biol Chem 269:18149-18154.

7. Doolittle RF (1992) Reconstructing history with 
amino acid sequences. In: Protein Science. 191200.

8. Bujacz A (2012) Structures of bovine, equine and leporine serum albumin. Acta Crystallogr Sect D Biol Crystallogr 68:1278-1289. https://doi.org/ 10.1107/S0907444912027047

9. Metcalf V, Brennan S, George P (2003) Using serum albumin to infer vertebrate phylogenies. Appl Bioinform 2:S97-S107.

10. Sarich VM, Wilson AC (1967) Rates of albumin evolution in primates. Proc Natl Acad Sci U S A 58:142-148. https://doi.org/10.1073/pnas.58.1.142

11. Harper ME (1983) Linkage of the evolutionarilyrelated serum albumin and alpha-fetoprotein genes within q11-22 of human chromosome 4 . Am J Hum Genet 35:565-572.

12. Gray JE, Doolittle RF (1992) Characterization, primary structure, and evolution of lamprey plasma albumin. Protein Sci 1:289-302. https:// doi.org/10.1002/pro.5560010211

13. Nishio H, Heiskanen M, Palotie A, Bélanger L, Dugaiczyk A (1996) Tandem arrangement of the human serum albumin multigene family in the sub-centromeric region of 4q: Evolution and chromosomal direction of transcription. $\mathrm{J}$ Mol Biol 259:113-119. https://doi.org/10.1006/ jmbi.1996.0306

14. Quinlan GJ, Martin GS, Evans TW (2005) Albumin: Biochemical properties and therapeutic potential. Hepatology 41:1211-1219.

15. Pietrangelo A, Panduro A, Chowdhury JR, Shafritz DA (1992) Albumin gene expression is downregulated by albumin or macromolecule infusion in the rat. J Clin Invest 89:1755-1760. https:// doi.org/10.1172/JCI115778

16. Pyzik M, Sand KMK, Hubbard JJ, Andersen JT, Sandlie I, Blumberg RS (2019) The neonatal Fc Receptor (FcRn): A misnomer? Front Immunol 10:1540. https://doi.org/10.3389/ fimmu.2019.01540.

17. Pincetic A, Bournazos S, Dilillo DJ, Maamary J, Wang TT, Dahan R, Fiebiger BM, Ravetch JV. (2014) Type i and type II Fc receptors regulate innate and adaptive immunity. Nat Immunol 15:707-716. https://doi.org/10.1038/ni.2939

18. Nakashima F, Shibata T, Kamiya K, Yoshitake J, Kikuchi R, Matsushita T, Ishii I, Giménez-Bastida JA, Schneider C, Uchida K (2018) Structural and functional insights into S-thiolation of human serum albumins. Sci Rep 8:932. https://doi.org/ 10.1038/s41598-018-19610-9

19. Tabata F, Wada Y, Kawakami S, Miyaji K (2021) Serum albumin redox states: More than oxidative stress biomarker. Antioxidants 10:503. https:// doi.org/10.3390/antiox10040503

20. Kragh-Hansen U, Brennan SO, Galliano M, Sugita O (1990) Binding of warfarin, salicylate, and diazepam to genetic variants of human serum albumin with known mutations. Mol Pharmacol 37:238-242

21. Fasano M, Curry S, Terreno E, Galliano M, Fanali G, Narciso P, Notari S, Ascenzi P (2005) The extraordinary ligand binding properties of human serum albumin. IUBMB Life 57:787-796. https://doi.org/10.1080/15216540500404093

22. Ascenzi P, Bocedi A, Notari S, Fanali G, Fesce R, Fasano M (2006) Allosteric Modulation of Drug Binding to Human Serum Albumin. MiniReviews Med Chem 6:483-489. https://doi.org/ 10.2174/138955706776361448

23. Ascenzi P, Fasano M (2010) Allostery in a monomeric protein: The case of human serum albumin. Biophys Chem 148:16-22. https://doi.org/ 10.1016/j.bpc.2010.03.001

24. Goncharov NV, Belinskaya DA, Razygraev AV, Ukolov AI (2015) On the enzymatic activity of albumin. Russ J Bioorgan Chem 41:131-144. https://doi.org/10.1134/S1068162015020041

25. Belinskaia DA, Goncharov NV (2020) Theoretical and Practical Aspects of Albumin Esterase Activity. Russ J Bioorganic Chem 46:287-298. https://doi.org/10.1134/S1068162020030036

26. Belinskaia DA, Voronina PA, Shmurak VI, Vovk MA, Batalova AA, Jenkins RO, Goncharov NV (2020) The universal soldier: Enzymatic and non-enzymatic antioxidant functions of serum albumin. Antioxidants 9:1-29. https://doi.org/10.3390/antiox9100966

27. Kirby AJ, Hollfelder F, Tawfik DS (2000) Nonspecific catalysis by protein surfaces. Appl Biochem Biotechnol - Part A Enzym Eng Biotechnol 83:173-181. https://doi.org/10.1385/abab:83:1$3: 173$

28. Copley SD (2017) Shining a light on enzyme promiscuity. Curr Opin Struct Biol 47:167-175. https://doi.org/10.1016/j.sbi.2017.11.001

29. Yang G, Miton CM, Tokuriki N (2020) A mechanistic view of enzyme evolution. Protein Sci 29:1724-1747. https://doi.org/10.1002/pro.3901

30. Sanchez E, Lu S, Reed C, Schmidt J, Forconi M (2016) Kemp elimination in cationic micelles: Designed enzyme-like rates achieved through the addition of long-chain bases. J Phys Org Chem 29:185-189. https://doi.org/10.1002/poc.3515

31. Sakamoto S, Komatsu T, Ueno T, Hanaoka K, Urano Y (2017) Fluorescence detection of serum albumin with a turnover-based sensor utilizing Kemp elimination reaction. Bioorgan Med Chem 
Lett 27:3464-3467. https://doi.org/10.1016/ j.bmcl.2017.05.076

32. Röthlisberger D, Khersonsky O, Wollacott AM, Jiang L, DeChancie J, Betker J, Gallaher JL, Althoff EA, Zanghellini A, Dym O, Albeck S, Houk KN, Tawfik DS, Baker D (2008) Kemp elimination catalysts by computational enzyme design. Nature 453:190-195. https://doi.org/ 10.1038/nature 06879

33. Oettl K, Marsche G (2010) Redox State of Human Serum Albumin in Terms of Cysteine-34 in Health and Disease. In: Methods in Enzymology 181-195.

34. Michelis R, Sela S, Zeitun T, Geron R, Kristal B (2016) Unexpected normal colloid osmotic pressure in clinical states with low serum albumin. PLoS One 11:e0159839. https://doi.org/10.1371/ journal.pone.0159839

35. Nagumo K, Tanaka M, Chuang VTG, Setoyama H, Watanabe H, Yamada N, Kubota K, Tanaka M, Matsushita K, Yoshida A, Jinnouchi H, Anraku M, Kadowaki D, Ishima Y, Sasaki Y, Otagiri M, Maruyama T (2014) Cys34-cysteinylated human serum albumin is a sensitive plasma marker in oxidative stress-related chronic diseases. PLoS One 9:e85216. https://doi.org/ 10.1371/journal.pone.0085216

36. Kurano M, Yasukawa K, Ikeda H, Aoki J, Yatomi Y (2019) Redox state of albumin affects its lipid mediator binding characteristics. Free Radic Res 53:892-900. https://doi.org/10.1080/ 10715762.2019.1641603

37. Figueroa SM, Araos P, Reyes J, Gravez B, BarreraChimal J, Amador CA (2021) Oxidized albumin as a mediator of kidney disease. Antioxidants 10:113. https://doi.org/10.3390/antiox10030404

38. Turell L, Radi R, Alvarez B (2013) The thiol pool in human plasma: The central contribution of albumin to redox processes. Free Radic Biol Med 65:244-253. https://doi.org/10.1016/j.freeradbiomed.2013.05.050

39. Roche M, Rondeau P, Singh NR, Tarnus E, Bourdon E (2008) The antioxidant properties of serum albumin. FEBS Lett 582:1783-1787. https://doi.org/10.1016/j.febslet.2008.04.057

40. Taverna M, Marie AL, Mira JP, Guidet B (2013) Specific antioxidant properties of human serum albumin. Ann Intensive Care 3:1-7. https:// doi.org/10.1186/2110-5820-3-4

41. Pedersen AO, Jacobsen J (1980) Reactivity of the Thiol Group in Human and Bovine Albumin at $\mathrm{pH}$ 3-9, as Measured by Exchange with 2,2'-Dithiodipyridine. Eur J Biochem 106:291-295. https:// doi.org/10.1111/j.1432-1033.1980.tb06022.x
42. Agarwal RP, Phillips M, McPherson RA, Hensley P (1986) Serum albumin and the metabolism of disulfiram. Biochem Pharmacol 35:3341-3347. https://doi.org/10.1016/0006-2952(86)90433-8

43. Hurst R, Bao Y, Ridley S, Williamson G (1999) Phospholipid hydroperoxide cysteine peroxidase activity of human serum albumin. Biochem $\mathbf{J}$ 338(Pt 3)(Pt 3):723-728.

44. Cha MK, Kim IH (1996) Glutathione-linked thiol peroxidase activity of human serum albumin: A possible antioxidant role of serum albumin in blood plasma. Biochem Biophys Res Commun 222:619-625. https://doi.org/10.1006/ bbrc. 1996.0793

45. Lee H, Kim IH (2001) Thioredoxin-linked lipid hydroperoxide peroxidase activity of human serum albumin in the presence of palmitoyl coenzyme A. Free Radic Biol Med 30:327-333. https:// doi.org/10.1016/S0891-5849(00)00483-4

46. Iwao Y, Ishima Y, Yamada J, Noguchi T, KraghHansen U, Mera K, Honda D, Suenaga A, Maruyama T, Otagiri M (2012) Quantitative evaluation of the role of cysteine and methionine residues in the antioxidant activity of human serum albumin using recombinant mutants. IUBMB Life 64:450-454. https://doi.org/10.1002/iub.567

47. Harris ED (1991) Copper Transport: An Overview. Proc Soc Exp Biol Med 196:130-140. https://doi.org/10.3181/00379727-196-43171B

48. Karpenko MN, Ilyicheva EY, Muruzheva ZM, Milyukhina IV, Orlov YA, Puchkova LV (2018) Role of Copper Dyshomeostasis in the Pathogenesis of Parkinson's Disease. Bull Exp Biol Med 164:596-600. https://doi.org/10.1007/s10517018-4039-4

49. Laussac JP, Sarkar B (1984) Characterization of the Copper(II)- and Nickel(II)-Transport Site of Human Serum Albumin. Studies of Copper(II) and Nickel(II) Binding to Peptide 1-24 of Human Serum Albumin by $13 \mathrm{C}$ and $1 \mathrm{H}$ NMR Spectroscopy. Biochemistry 23:2832-2838. https:// doi.org/10.1021/bi00307a046

50. Sendzik M, Pushie MJ, Stefaniak E, Haas KL (2017) Structure and Affinity of $\mathrm{Cu}(\mathrm{I})$ Bound to Human Serum Albumin. Inorg Chem 56:15057$15065 . \quad$ https://doi.org/10.1021/acs.inorgchem.7b02397

51. Bar-Or D, Rael LT, Lau EP, Rao NKR, Thomas GW, Winkler JV, Yukl RL, Kingston RG, Curtis CG (2001) An analog of the human albumin $\mathrm{N}$-terminus (Asp-Ala-His-Lys) prevents formation of copper-induced reactive oxygen species. Biochem Biophys Res Commun 284:856-862. https://doi.org/10.1006/bbrc.2001.5042 
52. Gryzunov YA, Arroyo A, Vigne JL, Zhao Q, Tyurin VA, Hubel CA, Gandley RE, Vladimirov YA, Taylor RN, Kagan VE (2003) Binding of fatty acids facilitates oxidation of cysteine-34 and converts copper-albumin complexes from antioxidants to prooxidants. Arch Biochem Biophys 413:53-66. https://doi.org/10.1016/S00039861(03)00091-2

53. Jarabak R, Westley J (1991) Localization of the sulfur-cyanolysis site of serum albumin to subdomain 3-ab. J Biochem Toxicol 6:65-70. https:// doi.org/10.1002/jbt.2570060109

54. Ratliff BB, Abdulmahdi W, Pawar R, Wolin MS (2016) Oxidant mechanisms in renal injury and disease. Antioxidants Redox Signal. 25:119-146. https://doi.org/10.1089/ars.2016.6665

55. Zunszain PA, Ghuman J, McDonagh AF, Curry S (2008) Crystallographic Analysis of Human Serum Albumin Complexed with 4Z,15E-Bilirubin-IX $\alpha$. J Mol Biol 381:394-406. https://doi.org/10.1016/j.jmb.2008.06.016

56. Gounden V, Ngu M, Anastasopoulou C, Jialal I (2020) Fructosamine. In: Stat Pearls. StatPearls Publishing, Treasure Island (FL).

57. Belsare S, Coté G (2021) Development of a colorimetric paper fluidic dipstick assay for measurement of glycated albumin to monitor gestational diabetes at the point-of-care. Talanta 223. https:// doi.org/10.1016/j.talanta.2020.121728

58. Bettiga A, Fiorio F, Di Marco F, Trevisani F, Romani A, Porrini E, Salonia A, Montorsi F, Vago R (2019) The modern western diet rich in advanced glycation end-products (AGEs): An overview of its impact on obesity and early progression of renal pathology. Nutrients 11(8):1748. https://doi.org/10.3390/nu11081748

59. Bohlender JM, Franke S, Stein G, Wolf G (2005) Advanced glycation end products and the kidney. Am J Physiol Ren Physiol 289(4):F645-F659. https://doi.org/10.1152/ajprenal.00398.2004

60. Pötzsch S, Blankenhorn A, Navarrete Santos A, Silber RE, Somoza V, Simm A (2013) The effect of an AGE-rich dietary extract on the activation of $\mathrm{NF}-\kappa \mathrm{B}$ depends on the cell model used. Food Funct 4:1023-1031. https://doi.org/10.1039/ c3fo30349g

61. Vlassara H, Uribarri J (2014) Advanced glycation end products (AGE) and diabetes: Cause, effect, or both? Curr Diab Rep 14:453. https://doi.org/ 10.1007/s11892-013-0453-1

62. Frimat $M$, Daroux $M$, Litke $R$, Nevière $R$, Tessier FJ, Boulanger E (2017) Kidney, heart and brain: Three organs targeted by ageing and glycation. Clin Sci 131:1069-1092. https://doi.org/
10.1042/CS20160823

63. Fritz G (2011) RAGE: A single receptor fits multiple ligands. Trends Biochem Sci 36:625-632. https://doi.org/10.1016/j.tibs.2011.08.008

64. Gill V, Kumar V, Singh K, Kumar A, Kim JJ (2019) Advanced glycation end products (AGEs) may be a striking link between modern diet and health. Biomolecules 9(12):888. https://doi.org/ 10.3390/biom9120888

65. Smith PK (2017) Do advanced glycation endproducts cause food allergy? Curr Opin Allergy Clin Immunol 17:325-331. https://doi.org/ 10.1097/ACI.0000000000000385

66. Sukkar MB, Wood LG, Tooze M, Simpson JL, McDonald VM, Gibson PG, Wark PAB (2012) Soluble RAGE is deficient in neutrophilic asthma and COPD. Eur Respir J 39:721-729. https:// doi.org/10.1183/09031936.00022011

67. Morales ME, Rojas RA, Monasterio AV, González BI, Figueroa CI, Manques MB, Romero EJ, Llanos LJ, Valdés ME, Cofré LC (2013) Lesiones gástricas en pacientes infectados con Helicobacter pylori: Expresiyn de RAGE (receptor de productos de glicosilizaciyn avanzada) y otros inmunomarcadores. Rev Med Chil 141:1240-1248. https://doi.org/10.4067/S003498872013001000002

68. Kumar Pasupulati A, Chitra PS, Reddy GB (2016) Advanced glycation end products mediated cellular and molecular events in the pathology of diabetic nephropathy. Biomol Concepts 7:293299. https://doi.org/10.1515/bmc-2016-0021

69. Perkins TN, Oczypok EA, Milutinovic PS, Dutz RE, Oury TD (2019) RAGE-dependent VCAM-1 expression in the lung endothelium mediates IL-33-induced allergic airway inflammation. Allergy Eur J Allergy Clin Immunol 74:89-99. https://doi.org/10.1111/all.13500

70. Sotokawauchi A, Matsui T, Higashimoto Y, Yamagishi SI (2019) Fructose causes endothelial cell damage via activation of advanced glycation end products-receptor system. Diabetes Vasc Dis Res 16:556-561. https://doi.org/10.1177/ 1479164119866390

71. Wautier MP, Chappey O, Corda S, Stern DM, Schmidt AM, Wautier JL (2001) Activation of NADPH oxidase by AGE links oxidant stress to altered gene expression via RAGE. Am J Physiol Endocrinol Metab 280:E685-E694. https:// doi.org/10.1152/ajpendo.2001.280.5.e685

72. Tanaka N, Yonekura H, Yamagishi SI, Fujimori H, Yamamoto Y, Yamamoto H (2000) The receptor for advanced glycation end products is induced by the glycation products themselves 
and tumor necrosis factor- $\alpha$ through nuclear factor- $\kappa \mathrm{B}$, and by $17 \beta$-Estradiol through sp- 1 in human vascular endothelial cells. J Biol Chem 275:25781-25790. https://doi.org/10.1074/ jbc.M001235200

73. Li L-M, Hou D-X, Guo Y-L, Yang J-W, Liu Y, Zhang C-Y, Zen K (2011) Role of MicroRNA214-Targeting Phosphatase and Tensin Homolog in Advanced Glycation End Product-Induced Apoptosis Delay in Monocytes. J Immunol 186:2552-2560. https://doi.org/10.4049/jimmunol.1001633

74. Lyons TJ, Jenkins A (1997) Glycation, oxidation, and lipoxidation in the development of the complications of diabetes: a carbonyl stress hypothesis. Diabetes Rev 5:365-391.

75. Neviere R, Yu Y, Wang L, Tessier F, Boulanger E (2016) Implication of advanced glycation end products (Ages) and their receptor (Rage) on myocardial contractile and mitochondrial functions. Glycoconj J 33:607-617. https://doi.org/ 10.1007/s10719-016-9679-X

76. Ahmad S, Siddiqui Z, Rehman S, Khan MY, Khan H, Khanum S, Alouffi S, Saeed M (2017) A Glycation Angle to Look into the Diabetic Vasculopathy: Cause and Cure. Curr Vasc Pharmacol 15:352-364. https://doi.org/10.2174/ 1570161115666170327162639

77. Copur S, Siriopol D, Afsar B, Comert MC, Uzunkopru G, Sag AA, Ortiz A, Covic A, van Raalte DH, Cherney DZ, Rossing P, Kanbay M (2021) Serum glycated albumin predicts all-cause mortality in dialysis patients with diabetes mellitus: meta-analysis and systematic review of a predictive biomarker. Acta Diabetol 58:81-91. https:// doi.org/10.1007/s00592-020-01581-X

78. Vijayaraghavan B, Padmanabhan G, Ramanathan K (2020) Determination of serum glycated albumin and high sensitivity c-reactive protein in the insight of cardiovascular complications in diabetic chronic kidney disease patients. Afr Health Sci 20:308-313. https://doi.org/ 10.4314/ahs.v20i1.36

79. Giglio RV, Lo Sasso B, Agnello L, Bivona G, Maniscalco R, Ligi D, Mannello F, Ciaccio M (2020) Recent Updates and Advances in the Use of Glycated Albumin for the Diagnosis and Monitoring of Diabetes and Renal, Cerebro- and Cardio-Metabolic Diseases. J Clin Med 9:3634. https://doi.org/10.3390/jcm9113634

80. Sarmah S, Das S, Roy AS (2020) Protective actions of bioactive flavonoids chrysin and luteolin on the glyoxal induced formation of advanced glycation end products and aggregation of human serum albumin: In vitro and molecular docking analysis. Int $\mathbf{J}$ Biol Macromol 165:2275-2285. https://doi.org/10.1016/j.ijbiomac.2020.10.023

81. Rondeau P, Bourdon E (2011) The glycation of albumin: Structural and functional impacts. Biochimie 93:645-658. https://doi.org/10.1016/ j.biochi.2010.12.003

82. Das A, Basak P, Pramanik A, Majumder R, Ghosh A, Hazra S, Guria M, Bhattacharyya M, Banik SP (2020) Ribosylation induced structural changes in Bovine Serum Albumin: understanding high dietary sugar induced protein aggregation and amyloid formation. Heliyon 6:e05053. https:// doi.org/10.1016/j.heliyon.2020.e05053

83. Vlassopoulos A, Lean MEJ, Combet E (2013) Role of oxidative stress in physiological albumin glycation: A neglected interaction. Free Radic Biol Med 60:318-324. https://doi.org/10.1016/ j.freeradbiomed.2013.03.010

84. Ledesma-Osuna AI, Ramos-Clamont G, VázquezMoreno L (2008) Characterization of bovine serum albumin glycated with glucose, galactose and lactose. Acta Biochim Pol 55:491-497.

85. Soboleva A, Mavropulo-Stolyarenko G, Karonova T, Thieme D, Hoehenwarter W, Ihling C, Stefanov V, Grishina T, Frolov A (2019) Multiple glycation sites in blood plasma proteins as an integrated biomarker of type 2 diabetes mellitus. Int $\mathbf{J}$ Mol Sci 20:2329. https://doi.org/10.3390/ ijms20092329

86. Qiu H, Jin L, Chen J, Shi M, Shi F, Wang M, Li D, Xu X, Su X, Yin X, Li W, Zhou X, Linhardt RJ, Wang Z, Chi L, Zhang Q (2020) Comprehensive glycomic analysis reveals that human serum albumin glycation specifically affects the pharmacokinetics and efficacy of different anticoagulant drugs in diabetes. Diabetes 69:760-770. https://doi.org/10.2337/db19-0738

87. Korça E, Piskovatska V, Börgermann J, Navarrete Santos A, Simm A (2020) Circulating antibodies against age-modified proteins in patients with coronary atherosclerosis. Sci Rep 10:17105. https:// doi.org/10.1038/s41598-020-73877-5

88. Qian H, Cao Y, Sun J, Zu J, Ma L, Zhou H, Tang X, Li Y, Yu H, Zhang M, Bai Y, Xu C, Ishii N, Hashimoto T, Li X (2020) Anti-human serum albumin autoantibody may be involved in the pathogenesis of autoimmune bullous skin diseases. FASEB J 34:8574-8595. https://doi.org/ 10.1096/fj.201903247RR

89. Nass N, Bayreuther K, Simm A (2017) Systemic activation of $\mathrm{NF}-\kappa \mathrm{B}$ driven luciferase activity in transgenic mice fed advanced glycation end products modified albumin. Glycoconj J 34:157-161. 
https://doi.org/10.1007/s10719-017-9762-y

90. Freitas PAC, Ehlert LR, Camargo JL (2017) Glycated albumin: A potential biomarker in diabetes. Arch Endocrinol Metab 61:296-304. https:// doi.org/10.1590/2359-3997000000272

91. Roohk HV, Zaidi AR, Patel D (2018) Glycated albumin (GA) and inflammation: role of GA as a potential marker of inflammation. Inflamm Res 67:21-30. https://doi.org/10.1007/s00011-0171089-4

92. Prasanna G, Jing P (2021) Polyphenol binding disassembles glycation-modified bovine serum albumin amyloid fibrils. Spectrochim Acta Part A Mol Biomol Spectrosc 246:119001. https:// doi.org/10.1016/j.saa.2020.119001

93. Bourdon E, Loreau N, Blache D (1999) Glucose and free radicals impair the antioxidant properties of serum albumin. FASEB J 13:233-244. https:// doi.org/10.1096/fasebj.13.2.233

94. Chesne S, Rondeau P, Armenta S, Bourdon E (2006) Effects of oxidative modifications induced by the glycation of bovine serum albumin on its structure and on cultured adipose cells. Biochimie 88:1467-1477. https://doi.org/10.1016/j.biochi.2006.05.011

95. Martinez Fernandez A, Regazzoni L, Brioschi M, Gianazza E, Agostoni P, Aldini G, Banfi C (2019) Pro-oxidant and pro-inflammatory effects of glycated albumin on cardiomyocytes. Free Radic Biol Med 144:245-255. https://doi.org/10.1016/ j.freeradbiomed.2019.06.023

96. Belinskaia DA, Terpilovskii MA, Batalova AA, Goncharov NV (2019) Effect of Cys34 Oxidation State of Albumin on Its Interaction with Paraoxon according to Molecular Modeling Data. Russ J Bioorganic Chem 45:535-544. https://doi.org/ 10.1134/S1068162019060086

97. Anthony-Regnitz CM, Wilson AE, Sweazea KL, Braun EJ (2020) Fewer Exposed Lysine Residues May Explain Relative Resistance of Chicken Serum Albumin to In Vitro Protein Glycation in Comparison to Bovine Serum Albumin. J Mol Evol 88:653-661. https://doi.org/10.1007/ s00239-020-09964-y

98. Martinez del Rio C, Gutiérrez-Guerrero YT (2020) An Evolutionary Remedy for an Abominable Physiological Mystery: Benign Hyperglycemia in Birds. J Mol Evol 88:715-719. https://doi.org/ 10.1007/s00239-020-09970-0

99. Myers GJ, Wegner J (2017) Endothelial Glycocalyx and Cardiopulmonary Bypass. J Extra Corpor Technol 49:174-181.

100. Perrin RM, Harper SJ, Bates DO (2007) A role for the endothelial glycocalyx in regulating microvas- cular permeability in diabetes mellitus. Cell Biochem Biophys 49:65-72. https://doi.org/ 10.1007/s12013-007-0041-6

101. Bruegger D, Rehm M, Jacob M, Chappell D, Stoeckelhuber M, Welsch U, Conzen $P$, Becker BF (2008) Exogenous nitric oxide requires an endothelial glycocalyx to prevent postischemic coronary vascular leak in guinea pig hearts. Crit Care 12:R73. https://doi.org/10.1186/cc6913

102. Bundgaard M (1984) The three-dimensional organization of tight junctions in a capillary endothelium revealed by serial-section electron microscopy. J Ultrasructure Res 88:1-17. https:// doi.org/10.1016/S0022-5320(84)90177-1

103. Michel CC, Curry FE (1999) Microvascular permeability. Physiol Rev 79:703-761. https:// doi.org/10.1152/physrev.1999.79.3.703

104. Erickson HP (2009) Size and shape of protein molecules at the nanometer level determined by sedimentation, gel filtration, and electron microscopy. Biol Proced Online 11:32-51. https:// doi.org/10.1007/s12575-009-9008-X

105. Aukland K, Kramer GC, Renkin EM (1984) Protein concentration of lymph and interstitial fluid in the rat tail. Am J Physiol Hear Circ Physiol 247(1 Pt 2):H74-H79. https://doi.org/10.1152/ ajpheart.1984.247.1.h74

106. Rutili G, Arfors KE (1977) Protein Concentration in Interstitial and Lymphatic Fluids from the Subcutaneous Tissue. Acta Physiol Scand 99:1-8. https:// doi.org/10.1111/j.1748-1716.1977.tb10345.x

107. Millici AJ, Watrous NE, Stukenbrok H, Palade GE (1987) Transcytosis of albumin in capillary endothelium. J Cell Biol 105:2603-2612. https://doi.org/10.1083/jcb.105.6.2603

108. Miyawaki-Shimizu K, Predescu D, Shimizu J, Broman M, Predescu S, Malik AB (2006) siRNAinduced caveolin-1 knockdown in mice increases lung vascular permeability via the junctional pathway. Am J Physiol Lung Cell Mol Physiol 290:L405-L413. https://doi.org/10.1152/ ajplung.00292.2005

109. Schubert W, Frank PG, Razani B, Park DS, Chow CW, Lisanti MP (2001) Caveolae-deficient Endothelial Cells Show Defects in the Uptake and Transport of Albumin in Vivo. J Biol Chem 276:48619-48622. https://doi.org/10.1074/ jbc.C100613200

110. Larsen MT, Kuhlmann M, Hvam ML, Howard KA (2016) Albumin-based drug delivery: harnessing nature to cure disease. Mol Cell Ther 4:3. https:// doi.org/10.1186/s40591-016-0048-8

111. Armstrong SM, Khajoee V, Wang C, Wang T, Tigdi J, Yin J, Kuebler WM, Gillrie M, Davis SP, 
Ho M, Lee WL (2012) Co-regulation of transcellular and paracellular leak across microvascular endothelium by dynamin and Rac. Am J Pathol 180:1308-1323. https://doi.org/10.1016/ j.ajpath.2011.12.002

112. Schubert W, Frank PG, Woodman SE, Hyogo H, Cohen DE, Chow CW, Lisanti MP (2002) Microvascular hyperpermeability in caveolin-1 (-/-) knock-out mice. Treatment with a specific nitricoxide synthase inhibitor, L-name, restores normal microvascular permeability in Cav-1 null mice. J Biol Chem 277:40091-40098. https://doi.org/ 10.1074/jbc.M205948200

113. Berde CB, Hudson BS, Simoni RD, Sklar LA (1979) Human serum albumin. Spectroscopic studies of binding and proximity relationships for fatty acids and bilirubin. J Biol Chem 254:391-400.

114. Baldo G, Fellin R, Manzatoa E, Baiocchi MR, Ongaro G, Baggio G, Fabiani F, Pauluzzi S, Crepaldi G (1983) Characterization of hyperlipidemia $m$ two patients with analbuminemia. Clin Chim Acta 128:307-319. https://doi.org/ 10.1016/0009-8981(83)90330-3

115. Cormode EJ, Lyster DM, Israels S (1975) Analbuminemia in a neonate. J Pediatr 86:862-867. https://doi.org/10.1016/S0022-3476(75)80215-0

116. Schnitzer JE, Carley WW, Palade GE (1988) Albumin interacts specifically with a $60-\mathrm{kDa}$ microvascular endothelial glycoprotein. Proc Natl Acad Sci U S A 85:6773-6777. https://doi.org/ 10.1073/pnas.85.18.6773

117. Tiruppathi C, Song W, Bergenfeldt M, Sass P, Malik AB (1997) Gp60 activation mediates albumin transcytosis in endothelial cells by tyrosine kinase-dependent pathway. J Biol Chem 272:25968-25975. https://doi.org/10.1074/ jbc. 272.41 .25968

118. Kuebler WM, Wittenberg C, Lee WL, Reppien E, Goldenberg NM, Lindner K, Gao Y, WinotoMorbach S, Drab M, Mühlfeld C, Dombrowsky H, Ochs M, Schütze S, Uhlig S (2016) Thrombin stimulates albumin transcytosis in lung microvascular endothelial cells via activation of acid sphingomyelinase. Am J Physiol Lung Cell Mol Physiol 310:L720-L732. https:// doi.org/10.1152/ajplung.00157.2015

119. John TA, Vogel SM, Tiruppathi C, Malik AB, Minshall RD (2003) Quantitative analysis of albumin uptake and transport in the rat microvessel endothelial monolayer. Am J Physiol - Lung Cell Mol Physiol 284:L187-L196. https://doi.org/ 10.1152/ajplung.00152.2002

120. Sarapultsev AP, Rempel SV, Kuznetsova JuV, Sarapultsev GP (2016) Nanoparticle's interac- tions with biological objects (The Review). J Ural Med Acad Sci 3:97-111. (In Russ). https:// doi.org/10.22138/2500-0918-2016-15-3-97-111

121. Aird WC (2007) Phenotypic heterogeneity of the endothelium: II. Representative vascular beds. Circ Res 100:174-190. https://doi.org/10.1161/ 01.RES.0000255690.03436.ae.

122. Raheel $\mathrm{H}$, Ghaffari S, Khosraviani N, Mintsopoulos V, Auyeung D, Wang C, Kim YH, Mullen B, Sung HK, Ho M, Fairn G, Neculai D, Febbraio M, Heit B, Lee WL (2019) CD36 mediates albumin transcytosis by dermal but not lung microvascular endothelial cells: Role in fatty acid delivery. Am J Physiol - Lung Cell Mol Physiol 316:L740-L750. https://doi.org/10.1152/ ajplung.00127.2018

123. Goncharov NV, Popova PI, Avdonin PP, Kudryavtsev IV, Serebryakova MK, Korf EA, Avdonin PV (2020) Markers of Endothelial Cells in Normal and Pathological Conditions. Biochem Suppl Ser A Membr Cell Biol 14:167-183. https:// doi.org/10.1134/S1990747819030140

124. Park L, Wang G, Moore J, Girouard H, Zhou P, Anrather J, Iadecola C (2014) The key role of transient receptor potential melastatin-2 channels in amyloid- $\beta$-induced neurovascular dysfunction. Nat Commun 5:5318. https://doi.org/10.1038/ ncomms6318

125. Suresh K, Servinsky L, Reyes J, Undem C, Zaldumbide J, Rentsendorj O, Modekurty S, Dodd-o JM, Scott A, Pearse DB, Shimoda LA (2016) CD36 mediates H2O2-induced calcium influx in lung microvascular endothelial cells. Am J Physiol - Lung Cell Mol Physiol 312:L143L153. ajplung.00361.2016

126. Hawighorst $T$, Oura $H$, Streit M, Janes L, Nguyen L, Brown LF, Oliver G, Jackson DG, Detmar M (2002) Thrombospondin-1 selectively inhibits early-stage carcinogenesis and angiogenesis but not tumor lymphangiogenesis and lymphatic metastasis in transgenic mice. Oncogene 21:7945-7956. https://doi.org/10.1038/ sj.onc. 1205956

127. Febbraio M, Hajjar DP, Silverstein RL (2001) CD36: A class B scavenger receptor involved in angiogenesis, atherosclerosis, inflammation, and lipid metabolism. J Clin Invest 108:785-791. https://doi.org/10.1172/JCI14006

128. Ibrahimi A, Abumrad NA (2002) Role of CD36 in membrane transport of long-chain fatty acids. Curr Opin Clin Nutr Metab Care 5:139-145. https://doi.org/10.1097/00075197-20020300000004 
129. Glatz JFC, Luiken JJFP (2018) Dynamic role of the transmembrane glycoprotein CD36 (SR-B2) in cellular fatty acid uptake and utilization. J Lipid Res 59:1084-1093. https://doi.org/10.1194/ jlr.R082933

130. Peters T Jr (1977) Serum albumin: recent progress in the understanding of its structure and biosynthesis. Clin Chem 391-400.

131.van der Vusse GJ (2009) Albumin as fatty acid transporter. Drug Metab Pharmacokinet 24:300307. https://doi.org/10.2133/dmpk.24.300

132. Nergiz-Unal R, Rademakers T, Cosemans J, Heemskerk J (2011) CD36 as a Multiple-Ligand Signaling Receptor in Atherothrombosis. Cardiovasc Hematol Agents Med Chem 9:42-55. https:// doi.org/10.2174/187152511794182855

133. Nagase S, Shimamune K, Shumiya S (1979) Albumin-deficient rat mutant. Science 205:590591. https://doi.org/10.1126/science.451621

134. Lin MH, Khnykin D (2014) Fatty acid transporters in skin development, function and disease. Biochim Biophys Acta-Mol Cell Biol Lipids 1841:362-368. https://doi.org/10.1016/ j.bbalip.2013.09.016

135. Robertson S, Colombo ES, Lucas SN, Hall PR, Febbraio M, Paffett ML, Campen MJ (2013) CD36 mediates endothelial dysfunction downstream of circulating factors induced by $\mathrm{O} 3$ exposure. Toxicol Sci 134:304-311. https://doi.org/ $10.1093 /$ toxsci/kft107

136. Traoré B, Muanza K, Looareesuwan S, Supavej S, Khusmith S, Danis M, Viriyavejakul P, Gay F (2000) Cytoadherence characteristics of Plasmodium falciparum isolates in Thailand using an in vitro human lung endothelial cells model. Am $\mathbf{J}$ Trop Med Hyg 62:38-44. https://doi.org/ 10.4269/ajtmh.2000.62.38

137. Pillon NJ, Azizi PM, Li YE, Liu J, Wang C, Chan KL, Hopperton KE, Bazinet RP, Heit B, Bilan PJ, Lee WL, Klip A (2015) Palmitateinduced inflammatory pathways in human adipose microvascular endothelial cells promote monocyte adhesion and impair insulin transcytosis. Am J Physiol - Endocrinol Metab 309:E35-E44. https://doi.org/10.1152/ajpendo.00611.2014

138. Amore A, Cirina P, Conti G, Cerutti F, Bagheri N, Emancipator SN, Coppo R (2004) Amadori-configurated albumin induces nitric oxide-dependent apoptosis of endothelial cells: A possible mechanism of diabetic vasculopathy. Nephrol Dial Transplant 19:53-60. https:// doi.org/10.1093/ndt/gfg428

139. Moon JH, Chae MK, Kim KJ, Kim HM, Cha BS, Lee HC, Kim YJ, Lee BW (2012) Decreased endothelial progenitor cells and increased serum glycated albumin are independently correlated with plaque-forming carotid artery atherosclerosis in type 2 diabetes patients without documented Ischemic disease. Circ J 76:2273-2279. https:// doi.org/10.1253/circj.CJ-11-1499

140. Popov D, Simionescu M (2006) Cellular mechanisms and signalling pathways activated by high glucose and AGE-albumin in the aortic endothelium. Arch Physiol Biochem 112:265-273. https:// doi.org/10.1080/13813450601094573

141. Rubenstein DA, Maria Z, Yin W (2011) Glycated albumin modulates endothelial cell thrombogenic and inflammatory responses. J Diabetes Sci Technol 5:703-713. https://doi.org/10.1177/ 193229681100500325

142. Rubenstein DA, Maria Z, Yin W (2014) Combined incubation of platelets and endothelial cells with glycated albumin: Altered thrombogenic and inflammatory responses. Diabetes Vasc Dis Res 11:235-242. https://doi.org/10.1177/ 1479164114531298

143. Nizheradze K (2006) Concanavalin A, but not glycated albumin, increases subendothelial deposition of von Willebrand factor in vitro. Endothel J Endothel Cell Res 13:245-248. https://doi.org/ $10.1080 / 10623320600903916$

144. Wang S, Hirschberg R (2009) Diabetes-relevant regulation of cultured blood outgrowth endothelial cells. Microvasc Res 78:174-179. https:// doi.org/10.1016/j.mvr.2009.06.002

145. Rashid G, Benchetrit S, Fishman D, Bernheim J (2004) Effect of advanced glycation end-products on gene expression and synthesis of TNF- $\alpha$ and endothelial nitric oxide synthase by endothelial cells. Kidney Int 66:1099-1106. https://doi.org/ 10.1111/j.1523-1755.2004.00860.x

146. Wang HJ, Lo WY, Lin LJ (2013) Angiotensin-(17) decreases glycated albumin-induced endothelial interleukin-6 expression via modulation of miR-146a. Biochem Biophys Res Commun 430:1157-1163. https://doi.org/10.1016/ j.bbrc.2012.12.018

147. Bala K, Gomes J, Gohil NK (2011) Interaction of glycated human serum albumin with endothelial cells in a hemodynamic environment: Structural and functional correlates. Mol Biosyst 7:30363041. https://doi.org/10.1039/c1mb05015j

148. Kunt T, Forst T, Harzer O, Buchert G, Pfutzner A, Lobig M, Zschabitz A, Stofft E, Engelbach M, Beyer J (1998) The influence of advanced glycation endproducts (AGE) on the expression of human endothelial adhesion molecules. Exp Clin Endocrinol Diabetes 106:183- 
188. https://doi.org/10.1055/s-0029-1211974

149. Higai K, Shimamura A, Matsumoto K (2006) Amadori-modified glycated albumin predominantly induces E-selectin expression on human umbilical vein endothelial cells through NADPH oxidase activation. Clin Chim Acta 367:137-143. https://doi.org/10.1016/j.cca.2005.12.008

150. Paradela-Dobarro B, Bravo SB, Rozados-Luís A, González-Peteiro M, Varela-Román A, González-Juanatey JR, García-Seara J, Alvarez E (2019) Inflammatory effects of in vivo glycated albumin from cardiovascular patients. Biomed Pharmacother 113:108763. https://doi.org/ 10.1016/j.biopha.2019.108763

151. Rodiño-Janeiro BK, González-Peteiro M, Ucieda-Somoza R, González-Juanatey JR, Álvarez E (2010) Glycated albumin, a precursor of advanced glycation end-products, up-regulates NADPH oxidase and enhances oxidative stress in human endothelial cells: Molecular correlate of diabetic vasculopathy. Diabetes Metab Res Rev 26:550-558. https://doi.org/10.1002/dmrr.1117

152. Nagasu H, Satoh M, Kiyokage E, Kidokoro K, Toida K, Channon KM, Kanwar YS, Sasaki T, Kashihara N (2016) Activation of endothelial $\mathrm{NAD}(\mathrm{P}) \mathrm{H}$ oxidase accelerates early glomerular injury in diabetic mice. Lab Investig 96:25-36. https://doi.org/10.1038/labinvest.2015.128

153. Rodiño-Janeiro BK, Paradela-Dobarro B, Raposeiras-Roubín S, González-Peteiro M, GonzálezJuanatey JR, Álvarez E (2015) Glycated human serum albumin induces $\mathrm{NF}-\kappa \mathrm{B}$ activation and endothelial nitric oxide synthase uncoupling in human umbilical vein endothelial cells. J Diabetes Complications 29:984-992. https://doi.org/ 10.1016/j.jdiacomp.2015.07.016

154. Amore A, Cirina P, Mitola S, Peruzzi L, Gianoglio B, Rabbone I, Sacchetti C, Cerutti F, Grillo C, Coppo R (1997) Nonenzymatically glycated albumin (Amadori adducts) enhances nitric oxide synthase activity and gene expression in endothelial cells. Kidney Int 51:27-35. https:// doi.org/10.1038/ki.1997.4

155. Chakravarthy U, Hayes RG, Stitt AW, McAuley E, Archer DB (1998) Constitutive nitric oxide synthase expression in retinal vascular endothelial cells is suppressed by high glucose and advanced glycation end products. Diabetes 47:945-952. https://doi.org/10.2337/diabetes.47.6.945

156. Dobi A, Bravo SB, Veeren B, ParadelaDobarro B, Álvarez E, Meilhac O, Viranaicken W, Baret P, Devin A, Rondeau P (2019) Advanced glycation end-products disrupt human endothelial cells redox homeostasis: new insights into reactive oxygen species production. Free Radic Res 53:150-169. https://doi.org/ 10.1080/10715762.2018.1529866

157. Jing Cao, Zhang G, Liu Z, Xu Q, Li C, Cheng G, Shi R (2021) Peroxidasin promotes diabetic vascular endothelial dysfunction induced by advanced glycation end products via NOX2/ $\mathrm{HOCl} / \mathrm{Akt} / \mathrm{eNOS}$ pathway. Redox Biol 45:102031. https://doi.org/10.1016/ j.redox.2021.102031

158. Ravi R, Ragavachetty Nagaraj N, Subramaniam Rajesh B (2020) Effect of advanced glycation end product on paraoxonase 2 expression: Its impact on endoplasmic reticulum stress and inflammation in HUVECs. Life Sci 246:117397. https:// doi.org/10.1016/j.lfs.2020.117397

159. Soaita I, Yin W, Rubenstein DA (2017) Glycated albumin modifies platelet adhesion and aggregation responses. Platelets 28:682-690. https:// doi.org/10.1080/09537104.2016.1260703

160. Son KH, Son M, Ahn H, Oh S, Yum Y, Choi CH, Park KY, Byun K (2016) Age-related accumulation of advanced glycation end-products-albu$\min , \mathrm{S} 100 \beta$, and the expressions of advanced glycation end product receptor differ in visceral and subcutaneous fat. Biochem Biophys Res Commun 477:271-276.

https://doi.org/10.1016/ j.bbrc.2016.06.056

161. Takeshita Y, Sato R, Kanda T (2021) Bloodnerve barrier (BNB) pathology in diabetic peripheral neuropathy and in vitro human BNB model. Int J Mol Sci 22:1-15. https://doi.org/10.3390/ ijms22010062

162. Goldsammler M, Merhi Z, Buyuk E (2018) Role of hormonal and inflammatory alterations in obesity-related reproductive dysfunction at the level of the hypothalamic-pituitary-ovarian axis. Reprod Biol Endocrinol 16:45. https://doi.org/ 10.1186/s12958-018-0366-6

163. Kuniyasu A, Ohgami N, Hayashi S, Miyazaki A, Horiuchi S, Nakayama H (2003) CD36-mediated endocytic uptake of advanced glycation end products (AGE) in mouse 3T3-L1 and human subcutaneous adipocytes. FEBS Lett 537:85-90. https:// doi.org/10.1016/S0014-5793(03)00096-6

164. Harati Y (2007) Diabetic Neuropathies: Unanswered Questions. Neurol Clin 25:303-317. https://doi.org/10.1016/j.ncl.2007.01.002

165. Linn T, Ortac K, Laube H, Federlin K (1996) Intensive therapy in adult insulin-dependent diabetes mellitus is associated with improved insulin sensitivity and reserve: A randomized, controlled, prospective study over 5 years in newly diagnosed 
patients. Metabolism 45:1508-1513. https:// doi.org/10.1016/S0026-0495(96)90180-8

166. Ismail-Beigi F, Craven T, Banerji MA, Basile J, Calles J, Cohen RM, Cuddihy R, Cushman WC, Genuth S, Grimm RH, Hamilton BP, Hoogwerf B, Karl D, Katz L, Krikorian A, O'Connor P, Pop-Busui R, Schubart U, Simmons D, Taylor H, Thomas A, Weiss D, Hramiak I (2010) Effect of intensive treatment of hyperglycaemia on microvascular outcomes in type 2 diabetes: An analysis of the ACCORD randomised trial. Lancet 376:419-430. https:// doi.org/10.1016/S0140-6736(10)60576-4

167. Ang L, Jaiswal M, Martin C, Pop-Busui R (2014) Glucose Control and Diabetic Neuropathy: Lessons from Recent Large Clinical Trials. Curr Diab Rep 14:1-15. https://doi.org/10.1007/s11892014-0528-7

168. Lassén E, Daehn IS (2020) Molecular mechanisms in early diabetic kidney disease: Glomerular endothelial cell dysfunction. Int J Mol Sci 21:121. https://doi.org/10.3390/ijms21249456

169. Sol M, Kamps JAAM, van den Born J, van den Heuvel MC, van der Vlag J, Krenning G, Hillebrands JL (2020) Glomerular Endothelial Cells as Instigators of Glomerular Sclerotic Diseases. Front Pharmacol 11:573557. https://doi.org/ 10.3389/fphar.2020.573557

170. Dejana E, Hirschi KK, Simons M (2017) The molecular basis of endothelial cell plasticity. Nat Commun 8:14361. https://doi.org/10.1038/ ncomms 14361

171.Zeisberg EM, Tarnavski O, Zeisberg M, Dorfman AL, McMullen JR, Gustafsson E, Chandraker A, Yuan X, Pu WT, Roberts AB, Neilson EG, Sayegh MH, Izumo S, Kalluri R (2007) Endothelial-to-mesenchymal transition contributes to cardiac fibrosis. Nat Med 13:952961. https://doi.org/10.1038/nm1613

172. Ruan B, Duan JL, Xu H, Tao KS, Han H, Dou GR, Wang L (2021) Capillarized Liver Sinusoidal Endothelial Cells Undergo Partial Endothelial-Mesenchymal Transition to Actively Deposit Sinusoidal ECM in Liver Fibrosis. Front Cell Dev Biol 9:671081. https://doi.org/10.3389/ fcell.2021.671081

173. Adjuto-Saccone M, Soubeyran P, Garcia J, Audebert S, Camoin L, Rubis M, Roques J, Binétruy B, Iovanna JL, Tournaire R (2021) TNF- $\alpha$ induces endothelial-mesenchymal transition promoting stromal development of pancreatic adenocarcinoma. Cell Death Dis 12:649. https:// doi.org/10.1038/s41419-021-03920-4

174. Peng H, Li Y, Wang C, Zhang J, Chen Y,
Chen W, Cao J, Wang Y, Hu Z, Lou T (2016) ROCK1 Induces Endothelial-to-Mesenchymal Transition in Glomeruli to Aggravate Albuminuria in Diabetic Nephropathy. Sci Rep 6:20304. https:// doi.org/10.1038/srep20304

175. Oldfield MD, Bach LA, Forbes JM, Nikolic-Paterson D, McRobert A, Thallas V, Atkins RC, Osicka T, Jerums G, Cooper ME (2001) Advanced glycation end products cause epithelialmyofibroblast transdifferentiation via the receptor for advanced glycation end products (RAGE). J Clin Invest 108:1853-1863. https://doi.org/ 10.1172/JCI11951

176. Chen S, Cohen MP, Ziyadeh FN (2000) Amadori-glycated albumin in diabetic nephropathy: Pathophysiologic connections. Kidney Int Suppl 77:S40-S44. https://doi.org/10.1046/j.15231755.2000.07707.x

177. Chen S, Cohen MP, Lautenslager GT, Shearman CW, Ziyadeh FN (2001) Glycated albumin stimulates TGF- $\beta 1$ production and protein kinase $\mathrm{C}$ activity in glomerular endothelial cells. Kidney Int 59:673-681. https://doi.org/ 10.1046/j.1523-1755.2001.059002673.x

178. Patschan D, Schwarze K, Henze E, Patschan S, Müller GA (2016) Endothelial autophagy and Endothelial-to-Mesenchymal Transition (EndoMT) in eEPC treatment of ischemic AKI. J Nephrol 29:637-644. https://doi.org/10.1007/ s40620-015-0222-0

179. Wang J, Feng Y, Wang Y, Xiang D, Zhang X, Yuan F (2017) Autophagy regulates EndothelialMesenchymal transition by decreasing the phosphorylation level of Smad3. Biochem Biophys Res Commun 487:740-747. https://doi.org/10.1016/ j.bbrc.2017.04.130

180. Rodriguez-Morales AJ, Cardona-Ospina JA, Gutiérrez-Ocampo E, Villamizar-Peña R, Holguin-Rivera Y, Escalera-Antezana JP, AlvaradoArnez LE, Bonilla-Aldana DK, Franco-Paredes C, Henao-Martinez AF, Paniz-Mondolfi A, LagosGrisales GJ, Ramírez-Vallejo E, Suárez JA, Zambrano LI, Villamil-Gómez WE, BalbinRamon GJ, Rabaan AA, Harapan H, Dhama K, Nishiura H, Kataoka H, Ahmad T, Sah R (2020) Clinical, laboratory and imaging features of COVID-19: A systematic review and meta-analysis. Travel Med Infect Dis 34:101623. https:// doi.org/10.1016/j.tmaid.2020.101623

181. Rahmani-Kukia N, Abbasi A, Pakravan N, Hassan ZM (2020) Measurement of oxidized albumin: An opportunity for diagnoses or treatment of COVID-19. Bioorg Chem 105:104429. https:// doi.org/10.1016/j.bioorg.2020.104429 
182. Chiappalupi S, Salvadori L, Vukasinovic A, Donato R, Sorci G, Riuzzi F (2021) Targeting RAGE to prevent SARS-CoV-2-mediated multiple organ failure: Hypotheses and perspectives. Life Sci 272:119251. https://doi.org/10.1016/ j.lfs.2021.119251

183. Chiappalupi S, Salvadori L, Donato R, Riuzzi F, Sorci G (2021) Hyperactivated rage in comorbidities as a risk factor for severe covid-19-the role of rage-ras crosstalk. Biomolecules 11:876. https:// doi.org/10.3390/biom11060876

184. Dobi A, Rosanaly S, Devin A, Baret P, Meilhac O, Harry GJ, D'Hellencourt CL, Rondeau P (2021) Advanced glycation end-products disrupt brain microvascular endothelial cell barrier: The role of mitochondria and oxidative stress. Microvasc Res 133:104098. https://doi.org/ 10.1016/j.mvr.2020.104098

185. Swissa E, Serlin Y, Vazana U, Prager O, Friedman A (2019) Blood-brain barrier dysfunction in status epileptics: Mechanisms and role in epileptogenesis. Epilepsy Behav 101(Pt B):106285. https://doi.org/10.1016/j.yebeh.2019.04.03

186. Aird WC (2012) Endothelial cell heterogeneity. Cold Spring Harb Perspect Med 2:a006429. https://doi.org/10.1101/cshperspect.a006429

187. Ivens S, Kaufer D, Flores LP, Bechmann I, Zumsteg D, Tomkins O, Seiffert E, Heinemann U, Friedman A (2007) TGF- $\beta$ receptor-mediated albumin uptake into astrocytes is involved in neocortical epileptogenesis. Brain 130:535-547. https://doi.org/10.1093/brain/awl317

188. Kim SY, Senatorov VV, Morrissey CS, Lippmann K, Vazquez O, Milikovsky DZ, Gu F, Parada I, Prince DA, Becker AJ, Heinemann U, Friedman A, Kaufer D (2017) TGF- $\beta$ signaling is associated with changes in inflammatory gene expression and perineuronal net degradation around inhibitory neurons following various neurological insults. Sci Rep 7:7711. https://doi.org/ 10.1038/s41598-017-07394-3

189. Senatorov V V., Friedman AR, Milikovsky DZ, Ofer J, Saar-Ashkenazy R, Charbash A, Jahan N, Chin G, Mihaly E, Lin JM, Ramsay HJ, Moghbel A, Preininger MK, Eddings CR, Harrison HV, Patel R, Shen Y, Ghanim H, Sheng H, Veksler R, Sudmant PH, Becker A, Hart B, Rogawski MA, Dillin A, Friedman A, Kaufer D (2019) Blood-brain barrier dysfunction in aging induces hyperactivation of TGF- $\beta$ signaling and chronic yet reversible neural dysfunction. Sci Transl Med 11:eaaw8283. https://doi.org/ 10.1126/scitranslmed.aaw8283

190. Weissberg I, Wood L, Kamintsky L, Vazquez O,
Milikovsky DZ, Alexander A, Oppenheim H, Ardizzone C, Becker A, Frigerio F, Vezzani A, Buckwalter MS, Huguenard JR, Friedman A, Kaufer D (2015) Albumin induces excitatory synaptogenesis through astrocytic TGF- $\beta$ /ALK5 signaling in a model of acquired epilepsy following blood-brain barrier dysfunction. Neurobiol Dis $78: 115-125$. https://doi.org/10.1016/ j.nbd.2015.02.029

191. Vega-Zelaya L, Ortega GJ, Sola RG, Pastor J (2014) Plasma albumin induces cytosolic calcium oscilations and DNA synthesis in human cultured astrocytes. Biomed Res Int 2014:539140. https:// doi.org/10.1155/2014/539140

192. Gatta A, Verardo A, Bolognesi M (2012) Hypoalbuminemia. Intern Emerg Med 7:S193-199. https://doi.org/10.1007/s11739-012-0802-0

193. Fischer K, Kettunen J, Würtz P, Haller T, Havulinna AS, Kangas AJ, Soininen P, Esko T, Tammesoo ML, Mägi R, Smit S, Palotie A, Ripatti S, Salomaa V, Ala-Korpela M, Perola M, Metspalu A (2014) Biomarker Profiling by Nuclear Magnetic Resonance Spectroscopy for the Prediction of All-Cause Mortality: An Observational Study of 17,345 Persons. PLoS Med 11:e1001606. https://doi.org/10.1371/journal.pmed.1001606

194. Deelen J, Kettunen J, Fischer K, van der Spek A, Trompet S, Kastenmüller G, Boyd A, Zierer J, van den Akker EB, Ala-Korpela M, Amin N, Demirkan A, Ghanbari $M$, van Heemst D, Ikram MA, van Klinken JB, Mooijaart SP, Peters A, Salomaa V, Sattar N, Spector TD, Tiemeier $\mathrm{H}$, Verhoeven $\mathrm{A}$, Waldenberger $\mathrm{M}$, Würtz P, Davey Smith G, Metspalu A, Perola M, Menni C, Geleijnse JM, Drenos F, Beekman M, Jukema JW, van Duijn CM, Slagboom PE (2019) A metabolic profile of all-cause mortality risk identified in an observational study of 44,168 individuals. Nat Commun 10:3346. https://doi.org/ 10.1038/s41467-019-11311-9

195. Tsirpanlis G, Bagos P, Ioannou D, Bleta A, Marinou I, Lagouranis A, Chatzipanagiotou S, Nicolaou C, do Nascimento MM, Stenvinkel P, Riella M, Lindholm B (2005) Serum albumin: A late-reacting negative acute-phase protein in clinically evident inflammation in dialysis patients. Nephrol Dial Transplant 20:658-660. https:// doi.org/10.1093/ndt/gfh663

196. Ngan DTT, Binh NG, Lan LTH, Nguyen CTT, Huong PT (2019) Evaluation of urinary L-FABP as an early marker for diabetic nephropathy in type 2 diabetic patients. J Med Biochem 39:224230. https://doi.org/10.2478/jomb-2019-0037 
197. Chen L, Jin C, Chen L, Li M, Zhong Y, Xu Y (2021) Value of microalbuminuria in the diagnosis of heart failure with preserved ejection fraction. Herz 46:215-221. https://doi.org/10.1007/ s00059-020-04985-1

198. Arogundade FA (2020) Detection of Early Renal Disease In Children With Sickle Cell Anaemia Using Microalbuminuria As A Surrogate Marker. West Afr J Med 37:327

199. Hwang JC, Jiang MY, Lu YH, Wang CT (2015) Precedent fluctuation of serum hs-CRP to albumin ratios and mortality risk of clinically stable hemodialysis patients. PLoS One 10:e120266. https://doi.org/10.1371/journal.pone.0120266

200. Minigalin AD, Voitenko NG, Vorobyov AA, Korf EA, Novozhilov AV, Petukhova OV, Baranova TI, Goncharov NV (2015) Investigation of relations between physiological and biochemical parameters of human beings in dynamics after performing a maximal workload. Physiother Sport Med 132:14-18. (In Russ.)

201. Suominen A, Jahnukainen T, Ojala TH, Sarkola T, Turanlahti M, Saarinen-Pihkala UM, Jahnukainen K (2020) Long-term renal prognosis and risk for hypertension after myeloablative therapies in survivors of childhood high-risk neuroblastoma: A nationwide study. Pediatr Blood Cancer 67:e28209. https://doi.org/10.1002/pbc.28209

202. Violi F, Cangemi R, Romiti GF, Ceccarelli G, Oliva A, Alessandri F, Pirro M, Pignatelli P, Lichtner M, Carraro A, Cipollone F, D'Ardes D, Pugliese F, Mastroianni CM (2021) Is Albumin Predictor of Mortality in COVID-19? Antioxidants Redox Signal 35:139-142. https://doi.org/ 10.1089/ars.2020.8142

203. Fukuhara S, Yasukawa K, Sato M, Ikeda H, Inoguchi $\mathrm{Y}$, Etoh $\mathrm{T}$, Masakado $\mathrm{M}$, Umeda $\mathrm{F}$, Yatomi Y, Yamauchi T, Inoguchi T (2020) Clinical usefulness of human serum nonmercaptalbumin to mercaptalbumin ratio as a biomarker for diabetic complications and disability in activities of daily living in elderly patients with diabetes. Metabolism 103:153995. https://doi.org/10.1016/ j.metabol.2019.153995

204. Chen Z, He Y, Shi B, Yang D (2013) Human serum albumin from recombinant DNA technology: Challenges and strategies. Biochim Biophys Acta - Gen Subj 1830:5515-5525. https:// doi.org/10.1016/j.bbagen.2013.04.037

205. Liumbruno GM, Bennardello F, Lattanzio A, Piccoli P, Rossetti G (2009) Recommendations for the use of albumin and immunoglobulins. Blood Transfus. 7:216-234. https://doi.org/ 10.2450/2009.0094-09
206. Tullis JL (1977) Albumin: 1. Background and Use. JAMA J Am Med Assoc 237:355-360. https:// doi.org/10.1001/jama.1977.03270310039005

207. Melia D, Post B (2021) Human albumin solutions in intensive care: A review. J Intensive Care Soc 22:248-254. https://doi.org/10.1177/ 1751143720961245

208. Schneider F, Dureau A-F, Hellé S, Betscha C, Senger B, Cremel G, Boulmedais F, Strub J-M, Corti A, Meyer N, Guillot M, Schaaf P, MetzBoutigue M-H (2019) A Pilot Study on Continuous Infusion of $4 \%$ Albumin in Critically Ill Patients. Crit Care Explor 1:e0044. https:// doi.org/10.1097/cce.0000000000000044

209. Ikeda M, Ishima Y, Kinoshita R, Chuang VTG, Tasaka N, Matsuo N, Watanabe H, Shimizu T, Ishida T, Otagiri M, Maruyama T (2018) A novel S-sulfhydrated human serum albumin preparation suppresses melanin synthesis. Redox Biol 14:354360. https://doi.org/10.1016/j.redox.2017.10.007

210. Yilmaz M, Sebe A, Ay MO, Gumusay U, Topal M, Atli M, Icme F, Satar S (2013) Effectiveness of therapeutic plasma exchange in patients with intermediate syndrome due to organophosphate intoxication. Am J Emerg Med 31:953-957. https://doi.org/10.1016/ j.ajem.2013.03.016

211. Tarin Remohi MJ, Sanchez Arcos A, Santos Ramos B, Bautista Paloma J, Guerrero Aznar MD (2000) Costs related to inappropriate use of albumin in Spain. Ann Pharmacother 34:1198-1205. https://doi.org/10.1345/aph.19385

212. Arola-Arnal A, López De Las Hazas MC, IglesiasCarres L, Mantilla-Escalante DC, Suárez M, Busto R, Visioli F, Bladé C, Dávalos A (2020) Exosomes transport trace amounts of (poly)phenols. Food Funct 11:7784-7792. https://doi.org/ $10.1039 / \mathrm{d} 0$ fo0 $1824 \mathrm{~d}$

213. Sakurai K, Kato T, Tanabe H, TaguchiAtarashi N, Sato Y, Eguchi A, Watanabe M, Ohno H, Mori C (2020) Association between gut microbiota composition and glycoalbumin level during pregnancy in Japanese women: Pilot study from Chiba Study of Mother and Child Health. J Diabetes Investig 11:699-706. https://doi.org/ 10.1111/jdi.13177

214. Hong M, Zhang R, Liu Y, Wu Z, Weng P (2021) The interaction effect between tea polyphenols and intestinal microbiota: Role in ameliorating neurological diseases. J Food Biochem 2021:e13870. https://doi.org/10.1111/jfbc.13870

215. Vlassopoulos A, Lean MEJ, Combet E (2014) Protein-phenolic interactions and inhibition of glycation-combining a systematic review and 
experimental models for enhanced physiological relevance. Food Funct 5:2646-2655. https:// doi.org/10.1039/c4fo00568f

216. Harris GK, Qian Y, Leonard SS, Sbarra DC, Shi X (2006) Luteolin and chrysin differentially inhibit cyclooxygenase-2 expression and scavenge reactive oxygen species but similarly inhibit prostaglandin-E 2 formation in RAW 264.7 cells. J Nutr 136:1517-1521. https://doi.org/10.1093/ jn/136.6.1517

217. Khan MWA, Al Otaibi A, Sherwani S, Khan WA,
Alshammari EM, Al-Zahrani SA, Saleem M, Khan SN, Alouffi S (2020) Glycation and oxidative stress increase autoantibodies in the elderly. Molecules 25:3675. https://doi.org/10.3390/molecules 25163675

218. Anwar S, Khan S, Almatroudi A, Khan AA, Alsahli MA, Almatroodi SA, Rahmani AH (2021) A review on mechanism of inhibition of advanced glycation end products formation by plant derived polyphenolic compounds. Mol Biol Rep 48:787805. https://doi.org/10.1007/s11033-020-06084-0 